\title{
An assessment of the minimum timing of ice free conditions of the western Laurentide Ice Sheet
}

\author{
Evan J. Gowan \\ Research School of Earth Sciences, The Australian National University, Acton 2601, ACT, Australia
}

\section{A R T I C L E I N F O}

\section{Article history:}

Received 22 November 2012

Received in revised form

27 May 2013

Accepted 3 June 2013

Available online

\section{Keywords:}

Laurentide Ice Sheet

Ice sheet retreat

Lake Agassiz

Radiocarbon dating

Cosmogenic dating

Luminescence dating

Ice sheet modelling

Younger Dryas

Deglaciation

Reservoir corrections

\begin{abstract}
A B S T R A C T
This study presents an investigation of the minimum timing of retreat of the western Laurentide Ice Sheet, which covered parts of Canada and the northern United States during the Wisconsin glaciation. The retreat of the ice sheet is poorly constrained due to low spatial resolution of chronological data that indicate ice free conditions. A limitation of radiocarbon and luminescence dating methods is that it is only possible to determine the time when it is certain that ice is absent from a region, which may differ substantially from the true date of ice margin retreat. The minimum timing of ice free conditions is determined using a model of ice sheet retreat, inferred from landforms that formed during the late stages of glaciation, and extrapolating the calibrated probability distribution of chronological data in the opposite direction. The analysis excludes radiocarbon samples from materials that have been shown to give artificially old ages, such as bulk sediments. The results of the analysis identify 55 dates that have the most impact on the model. The retreat of the western Laurentide Ice Sheet commenced by at least $15000 \mathrm{cal} \mathrm{yr} \mathrm{BP}$, while the minimum timing of ice free conditions between the Laurentide Ice Sheet and the Cordillera is after $11000 \mathrm{cal}$ yr BP. A lack of data in the Keewatin sector prevents the determination of a precise timing of ice free conditions in the last vestiges of the Laurentide Ice Sheet. The model provides a guide to where additional samples could improve chronological control on ice margin location.
\end{abstract}

(c) 2013 Elsevier Ltd. All rights reserved.

\section{Introduction}

The Laurentide Ice Sheet covered most of Canada and parts of the northern United States, reaching a maximum extent at the Last Glacial Maximum, between 26.5 and 19 ka (Clark et al., 2009). The ice sheet retreated over a period of 14 000-16 000 years, affecting global climate and sea level. Dyke and Prest (1987) and Dyke (2004) presented reconstructions of the ice sheet margin during the retreat of the Laurentide Ice Sheet, based on median ages of uncalibrated radiocarbon dates (Dyke et al., 2003), glacial geomorphological features (i.e. moraines, ice contact deltas, meltwater channels), and glacial flow features that indicate the most likely direction of ice retreat. Uncertainties in margin position are one of the largest potential sources of error in ice sheet reconstructions and models (i.e. Tarasov et al., 2012). In this paper, I create a model of the minimum timing of ice free conditions in the western Laurentide Ice Sheet. The model is developed using techniques similar to those applied by past workers such as Dyke and Prest (1987) and Dyke (2004) though, instead of determining a model of margin positions,

E-mail address: evan.gowan@anu.edu.au. chronological data are extrapolated in the direction opposite of retreat to determine the minimum timing of retreat. These results can be used as constraints for ice sheet models, by determining the region certain to be ice free for any time period. The model also serves as a basis for determining where more data would best improve temporal controls of ice margin reconstructions.

The western Laurentide Ice Sheet includes the region of ice that flowed from the Keewatin sector (Fig. 1). It converged with the Cordillera Ice Sheet to the west, and extended into northern midwestern United States (Dyke, 2004). The easternmost boundary of this sector lay in northwestern Ontario and Manitoba, where ice from northeastern sectors also influenced the direction of flow. The retreat of ice in this region has implications for major climatic events (i.e. Tarasov and Peltier, 2005; Broecker, 2006; Gregoire et al., 2012), the drainage of glacial lakes (i.e. Fisher et al., 2002; Teller et al., 2002; Teller and Leverington, 2004; Broecker, 2006; Fisher et al., 2009; Fisher and Lowell, 2012), and the migration of mammals in deglacial and post-glacial North America (i.e. Meltzer, 2003; Burns, 2010).

It is important to recognise that radiocarbon dates only provide a minimum timing of retreat. There is an unknown period of time between when ice retreated from a region and when organisms 


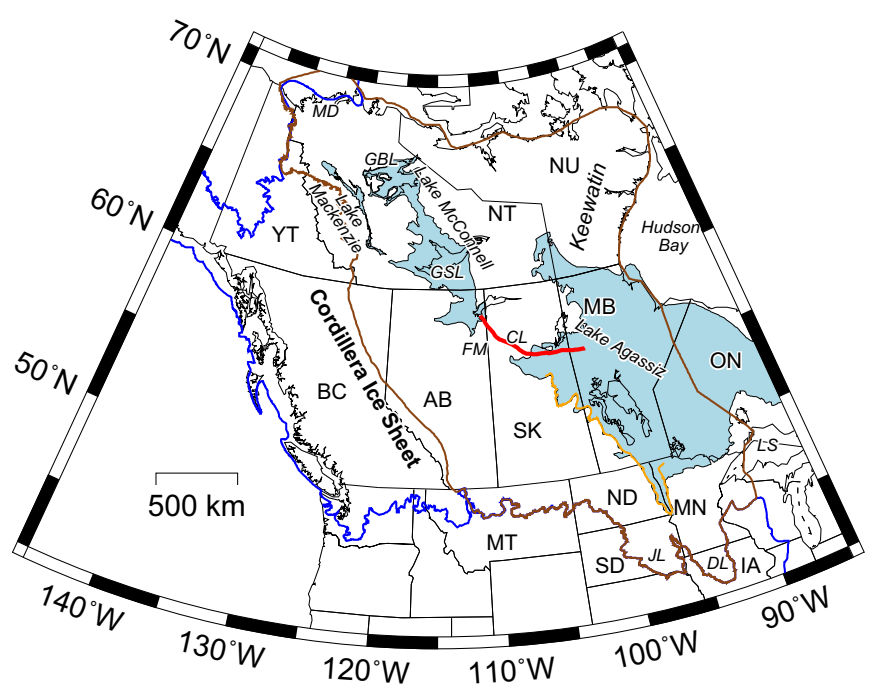

Fig. 1. Map of the western Laurentide Ice Sheet and adjacent areas. The maximum extent of late Wisconsin ice is shown by the blue line, based on maps by Dyke (2004), and the "Illinoian" maximum extent by Fullerton et al. (1995, 2004, 2007), Hallberg et al. (1994) and Swinehart et al. (1994), which is now suspected to date to the late Wisconsinan (Jackson et al., 2011). The brown outline is the area investigated in this study, which is bounded on the west by the convergence zone of the Laurentide and Cordillera ice sheets. The area covered by glacial lakes Mackenzie (Smith, 1992) McConnell (Smith, 1994) and Agassiz (Leverington and Teller, 2003) are shown in light blue. The Upper Campbell Beach, the most extensive beach of Lake Agassiz, is shown in orange (Fisher and Lowell, 2012). The location of the Cree Lake Moraine (CL) is shown with a red line (Fulton, 1995). Locations mentioned in this paper: MT - Montana; ND North Dakota; SD - South Dakota; MN - Minnesota; IA - Iowa; BC - British Columbia; AB - Alberta; SK - Saskatchewan; MB - Manitoba; ON - Ontario; YT - Yukon; NT Northwest Territories; NU - Nunavut; JL - James Lobe; DL - Des Moines Lobe; GSL Great Slave Lake; GBL - Great Bear Lake; LS - Lake Superior; MD - Mackenzie Delta; FM - Fort McMurray region. (For interpretation of the references to colour in this figure legend, the reader is referred to the web version of this article.)

reoccupied it. The full suite of available radiocarbon dates also represent results from a wide variety of studies, many that were not attempting to constrain the precise timing of retreat. These data nevertheless provide estimates of the minimum timing of ice free conditions. During the past 20 years, researchers have also started to use surface exposure and luminescence dating methods to constrain the retreat of the Laurentide Ice Sheet (i.e. Duk-Rodkin et al., 1996; Jackson et al., 1997, 1999, 2011; Wolfe et al., 2004, 2007; Davis et al., 2006; Lepper et al., 2007; Murton et al., 2007; Munyikwa et al., 2011). These methods provide an independent means of determining the timing of ice sheet retreat from radiocarbon dating, and they do not require the presence of organic material to determine that ice is absent.

Dates in key locations provide the minimum timing of ice free conditions for their location and deglaciated regions in the direction opposite of retreat. The direction of retreat can be inferred directly using marginal features such as end moraines or, when absent, from ice flow indicators and eskers, which is the basis for margin reconstructions (e.g. Dyke, 2004). The continuity of ice free areas laterally from the sample may be less certain and the confidence should be down-weighted.

In this paper, I determine the minimum timing of ice free conditions of the area covered by the western Laurentide Ice Sheet. This involves assessing the currently available chronological data that indicate ice free conditions, and rejecting samples that may be affected by contamination and give anomalously old ages. I produce a spatial and temporal model of the minimum timing of retreat using the calibrated age of these data.

\section{Dating methods}

\subsection{Radiocarbon dating}

Temporal control on the retreat of the western Laurentide Ice Sheet comes primarily from radiocarbon dates. An updated version of the compilation by Dyke et al. (2003) (A.S. Dyke, pers. comm. 2010) was the source of the majority of radiocarbon dates used in this study. These are supplemented by samples from recent studies that have focused on the chronology of strandlines and drainage routes of glacial Lake Agassiz (e.g. Lowell et al., 2005, 2009; Teller et al., 2005; Yansa and Ashworth, 2005; Boyd, 2007; Fisher, 2007; Lepper et al., 2007; Fisher et al., 2009; Anderson, 2012; Fisher and Lowell, 2012), other studies focussing on ice sheet retreat, glacial geology and other glacial lakes (e.g. Fulton et al., 2004; Dredge and McMartin, 2005; Bateman and Murton, 2006; Little, 2006; Couch and Eyles, 2008; Huntley et al., 2008; Yu et al., 2010; Breckenridge et al., 2012) plus other studies that did not have a particular focus on the retreat of the Laurentide Ice Sheet but nonetheless provide evidence of ice free conditions (a compilation of samples used in this study is available in the Supplementary material).

Radiocarbon dates need to be calibrated to account for changes in the concentration of ${ }^{14} \mathrm{C}$ in the atmosphere. OxCal 4.1 (Bronk Ramsey, 2009) is used to calibrate dates in this study. Terrestrial samples were calibrated using the IntCal09 curve, while marine samples used the Marine09 curve (Reimer et al., 2009). Calibrated radiocarbon dates are denoted as "cal yr BP", while uncalibrated dates are denoted as " ${ }^{14} \mathrm{C}$ yr BP". Ages reported in this paper are at the $95 \%$ confidence interval, rounded to the nearest hundred years, though the full calibrated distribution is used in the modelling.

Organisms that grew in marine environments have measured ages that are older than their true age due to the delay in incorporation of atmospheric ${ }^{14} \mathrm{C}$ into the water, the upwelling of ${ }^{14} \mathrm{C}$ deficient waters by currents, and the influx of glacial meltwater into the ocean (Hutchinson et al., 2004; Coulthard et al., 2010; Vickers et al., 2010). An estimation of the deficiency of ${ }^{14} \mathrm{C}$ in a modern reservoir is made by finding the difference between the true and apparent ages of pre-bomb molluscs of known age (i.e. McNeely et al., 2006). Subtracting that value from the apparent age of the samples gives an improved estimate of its true age. Coulthard et al. (2010) made an estimation of modern reservoir age by comparing the ages of molluscs of known age with their measured radiocarbon ages. The difference between the local reservoir age and the globally averaged value $(\Delta R)$ is subtracted before calibration. For samples from northern mainland Northwest Territories and Nunavut, the modern reservoir correction of $\Delta R=335 \pm 85$ is used (Coulthard et al., 2010). Deposit feeding molluscs, such as Portlandia arctica, can have a larger, unpredictable reservoir age compared to suspension feeder molluscs from the same region (England et al., 2013). Due to this, these species, along with samples where species identification are not provided, are excluded from the main analysis in this study.

The magnitude of the marine reservoir effect varied through time in glaciated regions (Barber et al., 1999; Kovanen and Easterbrook, 2002; Hutchinson et al., 2004; McNeely et al., 2006; Coulthard et al., 2010; Vickers et al., 2010), so the modern value may not be appropriate. For instance, Vickers et al. (2010) found that the postglacial reservoir offset in Hudson Strait was $\Delta R=615 \pm 15$, which is $375 \pm 25$ years larger than the modern value of $\Delta R=240 \pm 15$ (McNeely et al., 2006). Southampton Island, located at the northern end of Hudson Bay has a postglacial reservoir offset of $\Delta R=263 \pm 48$ (Ross et al., 2012). The island is situated at the boundary of two oceanographic subdivisions used 
by Coulthard et al. (2010). The postglacial reservoir age in that location is greater than the modern value for Hudson Bay $(\Delta R=110 \pm 65)$ and lower than the modern value of the Foxe Basin $(\Delta R=310 \pm 90)$, and $\Delta R=352 \pm 52$ years lower than the early postglacial offset in Hudson Strait (Vickers et al., 2010). Ross et al. (2012) attributed the lower postglacial reservoir offset on Southampton Island relative to Hudson Strait to the presence of noncalcareous Precambrian bedrock. Coulthard et al. (2010) separated Hudson Bay and James Bay into two regions, finding offsets of $\Delta R=110 \pm 65$ and $\Delta R=395 \pm 115$, respectively. Barber et al. (1999) found a modern marine reservoir offset of $\Delta R=310 \pm 50$ for southeastern Hudson Bay and James Bay. They stated that modern correction in the Hudson Bay region would be conservative compared to early postglacial time due to increased runoff from retreating ice sheets, and the abundance of freshly glacially eroded carbonate bedrock.

The apparent age of marine samples from southwestern Hudson Bay after deglaciation provide evidence that the reservoir age is greater than the modern value. The age of marine organisms found in southwestern Hudson Bay must postdate the 8.2 ka event, a climate change event associated with the drainage of lakes Agassiz and Ojibway into the northern Atlantic Ocean, which happened between 8490 and $8040 \mathrm{cal} \mathrm{yr}$ BP (Lewis et al., 2012). The final drainage event may correspond to when Hudson Bay became ice free (Barber et al., 1999), though initial drainage may have been subglacial (Roy et al., 2011). Regardless, the calibrated age of marine organisms in this region must postdate this drainage event, as ice within Hudson Bay would have blocked the incursion of marine water. An estimate of the timing of marine inundation into southwestern Hudson Bay was made using OxCal's "boundary" functionality (Fig. 2, Bronk Ramsey, 2009). A total of 18 marine shell samples dating between 8200 and $7000{ }^{14} \mathrm{C}$ yr BP from northern Manitoba, derived from Morlan et al. (2000), were used to model the beginning of marine inundation into Manitoba. The timing of the event was tested using no additional marine reservoir correction $(\Delta R=0)$, the modern value $(\Delta R=110 \pm 65$, Coulthard et al., $2010)$, and the sum of the modern correction and the additional offset of $375 \pm 25$ found in the Hudson Strait (Vickers et al., 2010; $\Delta R=470 \pm 100)$. The modelled age of marine inundation for northern Manitoba is older than the inferred timing of the $8.2 \mathrm{ka}$ event using the modern reservoir correction (Table 1, Fig. 2). The modelled age of marine inundation falls within the 8.2 ka event using the larger value $(\Delta R=470 \pm 100)$ (Table 1$)$. This $\Delta R$ value is used to correct marine samples from the Hudson Bay region. This correction is only a minimum value if the $8.2 \mathrm{ka}$ event was caused by subglacial drainage of the lakes (i.e. Lajeunesse and St-Onge, 2008), rather than the complete deglaciation of Hudson Bay that would have allowed sea water to enter the region.

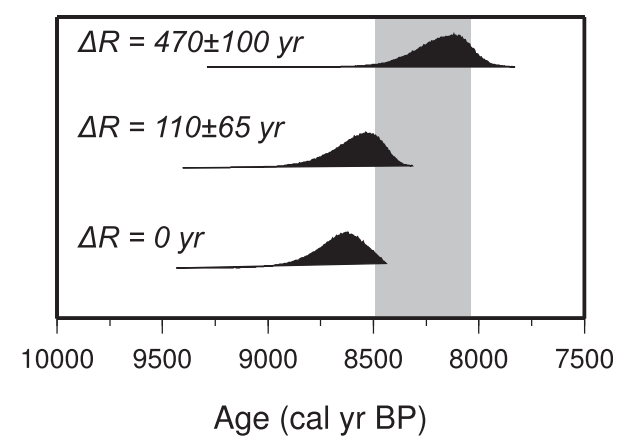

Fig. 2. Probability distributions for the timing of the initial inundation northern Manitoba by the Tyrrell Sea. The grey bar is the approximate timing of the 8.2 ka event (Lewis et al., 2012). The distributions correspond to models using the given $\Delta R$ values.
Table 1

Modelled age of the initial inundation of northern Manitoba by sea water.

\begin{tabular}{llll}
\hline$\Delta R$ & $95 \%$ probability range & Median age & Mode age \\
\hline 0 & $8895-8470$ & 8655 & 8630 \\
$110 \pm 65$ & $8920-8385$ & 8575 & 8535 \\
$470 \pm 100$ & $8520-7960$ & 8175 & 8120 \\
\hline
\end{tabular}

The incorporation of pre-glacial organic material, lignite, hydrocarbons, carbonate rocks, and hardwater effects can cause radiocarbon dates on bulk sediments to appear older than their true age (i.e. Deevey et al., 1954; Ogden, 1977; Nambudiri et al., 1980; MacDonald et al., 1991; Shore et al., 1995). In regions previously glaciated by the western Laurentide Ice Sheet, measurements of bulk sediment can be several hundred to over 1000 years older than contemporaneously deposited terrestrial macrofossils (MacDonald et al., 1991; Grimm et al., 2009). The heterogeneous composition of sediments and peat can cause variability in the apparent age of material taken from the same horizon (e.g. Brock et al., 2010, 2011). Abbott and Stafford (1996) have also showed that anomalously old ages can occur in lakes in the Arctic, even when the local bedrock geology does not contain carbonates. The age of such sediments may be influenced by the input of old material from around the basin (Bertrand et al., 2012). Before the advent of accelerator mass spectrometry (AMS) dating methods that allowed the measurement of small samples, bulk sediment, peat and gyttja were used often to constrain the timing of ice sheet retreat. It may be appropriate to use bulk sediment or peat samples if it is clear that the material is predominately terrestrial plant material (i.e. Nilsson et al., 2001), but often this information is not reported or known. Dyke et al. (2003) rejected most samples that were most likely affected by recycled carbon and hardwater effects, but kept samples where it was less clear. Other studies of the retreat of the western Laurentide Ice Sheet (e.g. Clayton and Moran, 1982; Teller, 1989; Arnold, 2002; Fisher, 2007; Fisher et al., 2009) have rejected samples where the material sampled could be contaminated. In this study, where the purpose is determining the minimum timing of deglaciation, samples that may give anomalously old ages, such as bulk sediments and peat, are rejected. A comparison of the minimum timing of retreat with and without these samples is presented in the Supplementary material.

\subsection{Surface exposure and luminescence}

Surface exposure and luminescence methods are alternative dating methods that have been used to provide estimates on when regions became ice free, and avoids the problem with the unknown duration of time between deglaciation and the colonization of plants and animals (e.g. Jackson et al., 1997, 1999; Wolfe et al., 2004; Munyikwa et al., 2011). Surface exposure dating involves the measurement of the relative abundance of elements formed by cosmogenic radiation bombarding exposed rock (Zreda and Phillips, 2000; Gosse and Phillips, 2001). This method requires estimates of the erosion rate and how shielded the rock is from the direct exposure (i.e. snow cover, topographical relief). The studies that presented surface exposure dates concluded that these effects were small (e.g. Jackson et al., 1997, 1999; Davis et al., 2006; Bednarski and Smith, 2007). There also is the possibility that the rock was exposed prior to glaciation, which increases the apparent age of exposure (e.g. Jackson et al., 1997), or that the samples first became exposed after eroding out of glacial deposits, giving an age that post-dates deglaciation (e.g. Jackson et al., 1999). Due to these uncertainties, surface exposure dates are not used in the main analysis of the minimum timing of retreat. Luminescence dates 
provide the timing of deposition and burial of silicate minerals such as quartz and feldspar (Forman et al., 2000). To acquire an accurate date, the minerals must be sufficiently exposed to light prior to burial to reset the signal. Dates from aeolian deposits are likely to have been fully exposed, and accurately record the timing of burial (e.g. Wolfe et al., 2004; Bateman and Murton, 2006; Munyikwa et al., 2011). Murton et al. (2010) collected samples from fluvial sediments, that are less likely to have been fully exposed to light. Since the material from that study was derived from post-glacial aeolian deposits, the dates should be reliable for the purposes of finding the minimum timing of retreat. Samples from studies dating strandlines were from the littoral zone of beaches (i.e. Lepper et al., 2007, 2011), maximizing the likelihood of material being exposed prior to burial. Ages from these two methods are reported in this paper as "ka" with $1 \sigma$ error ranges. Luminescence and surface exposure ages are reported relative to the year the sample was measured, so in the modelling they are adjusted to be relative to 1950 A.D. for consistency with calibrated radiocarbon dates ages.

\section{Chronological constraints on the minimum timing of retreat of the western Laurentide Ice Sheet}

\subsection{Radiocarbon dates}

There are 604 radiocarbon dates available in the study region, most derived from an updated version of the compilation by Dyke et al. (2003) (A.S. Dyke pers. comm. 2010). A literature search was completed to find additional relevant radiocarbon samples from the study area. ${ }^{1}$ The distribution of samples is biased to areas in the southern part of the study area and areas along the northern mainland coast (Fig. 3). There are few samples in the interior of mainland Northwest Territories and Nunavut, as well as northern Manitoba and Saskatchewan. For the analysis of the minimum timing of retreat, the radiocarbon dates were grouped into four different classes. There are 313 samples that are terrestrial materials, such as wood, charcoal, terrestrial plants and mammal fossils. These samples are regarded as having reliable dates. There are 49 samples of suspension feeding marine molluscs, and are deemed to be reliable after reservoir correction. There are 225 samples of sediment, peat, soil, marl, gyttja and aquatic plants and animals that have the potential of being affected by hardwater effects and old carbon, and were excluded from the main analysis. There are 17 samples that are deposit feeding marine molluscs, or where the species are not stated, which are excluded from the main analysis.

\subsection{Luminescence dates}

There are 84 luminescence dates that are relevant for determining the minimum timing of retreat in the study area. These data were collected for dating post-glacial sand dune formation (Wolfe et al., 2004, 2006, 2007; Munyikwa et al., 2011), the age of strandlines of glacial Lake Agassiz (Lepper and Sager, 2000; Lepper et al., 2007, 2011, 2013; Fisher et al., 2008) and late glacial events in the Mackenzie Delta (Bateman and Murton, 2006; Murton et al., 2007, 2010). In cases where a strandline can be traced to the contemporaneous ice margin, they provide a minimum timing of retreat for the entire length (i.e. Fisher and Lowell, 2012). Though not done in the main analysis, the Herman and Norcross strandlines impact the model from the period between 14000 and $13000 \mathrm{cal}$ yr BP, while the Campbell strandline (Fig. 1) has a more limited impact from 11000 to $10000 \mathrm{cal} \mathrm{yr} \mathrm{BP.}{ }^{2}$

\footnotetext{
1 A list of samples used in this study is included in the Supplementary material.

2 Models including strandlines are included in the Supplementary material.
}

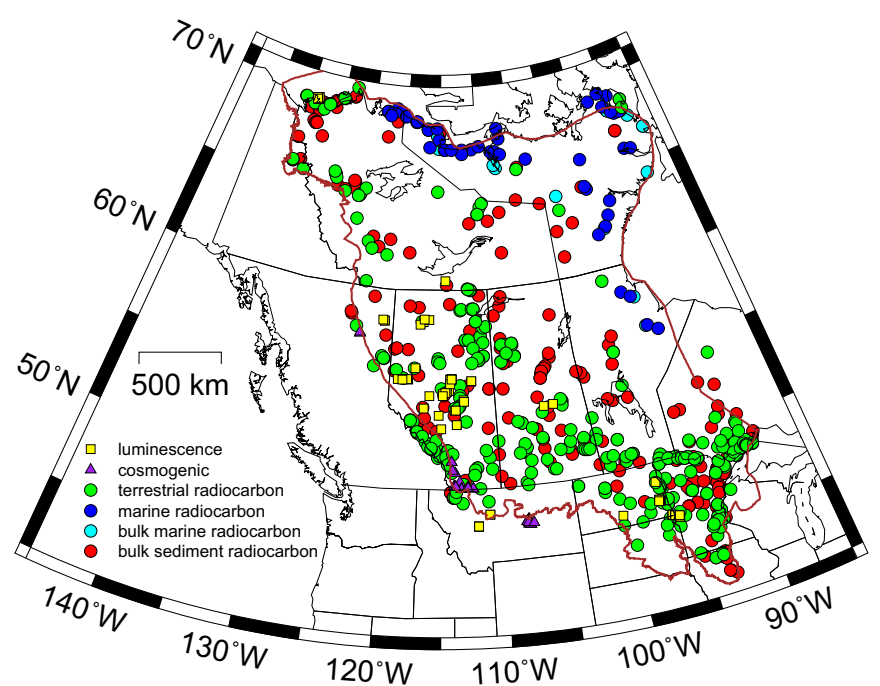

Fig. 3. Map showing the location of chronological constraints relevant to the minimum timing of the retreat of the western Laurentide Ice Sheet. The brown outline is the area investigated in this study.

\subsection{Surface exposure dates}

There are 38 surface exposure dates relevant to deglaciation of the western Laurentide Ice Sheet. Most of these are ${ }^{36} \mathrm{Cl}$ dates that come from locations near the convergence zone of the Laurentide and Cordilleran ice sheets (Jackson et al., 1997, 1999, 2011; Bednarski and Smith, 2007). The ages of the samples are variable (20-10 ka), and depend in part on the determination of an appropriate erosion rate.

\section{Direction of ice margin retreat}

The determination of the direction of retreat assumes time transgressive formation of landforms, such as moraines, streamlined landforms and eskers. This methodology has been used in prior margin models (i.e. Bryson et al., 1969; Prest, 1969; Boulton et al., 1985; Dyke and Prest, 1987; Dyke, 2004). End and recessional moraines and crevasse-fill ridges formed roughly parallel to the recessional ice margin, while flutings, drumlins and other streamlined landforms that formed in the recessional phase are roughly perpendicular to the margin. Eskers and meltwater channels are other features that can form perpendicular to the direction of late stage ice retreat (Clark and Walder, 1994; Kleman and Borgström, 1996). In the Keewatin sector, the final retreat may have been by downwasting of an inactive ice sheet (Aylsworth and Shilts, 1989a), and eskers may better reflect the direction of retreat than flutings. Landforms inferred to have formed prior to deglaciation and had been overridden were excluded from the model.

Glacial landforms used to infer the direction of margin retreat are derived from a variety of published surficial geology maps, with scales ranging between 1:50 000 to 1:5000 000. Retreat features for the northern United States and adjacent regions of Canada are sourced from USGS 1:1000 000 Quaternary Geological Atlas of the United States maps (Goebel et al., 1983; Hallberg et al., 1994; Swinehart et al., 1994; Sado et al., 1995; Fullerton et al., 1995, 2000, 2007). A map of glacial limits by Fullerton et al. (2004) is used to determine the inferred direction of retreat in Montana. Features for northern and central Manitoba come from a preliminary map of glacial features (Trommelen and Ross, 2010; McMartin et al., 2010; Trommelen et al., 2012a, b; M. Trommelen 
pers. comm, 2012). Glacial features for Saskatchewan come from the Geological Atlas of Saskatchewan (McMartin et al., 2010; Hanson et al., 2011; Slimmon, 2011). In most of Alberta, recent interpretations of glacial features by Evans et al. (2008) are used. Features for much of mainland Northwest Territories are derived from Brown et al. (2011). Features for the Keewatin sector are predominantly derived from Aylsworth and Shilts (1989b). These sources are complemented by smaller scale maps in Alberta, British Columbia, Yukon, Northwest Territories and mainland Nunavut (a full list of sources is included in the Supplementary material). In regions without coverage, the 1:5000 000 surficial materials map of Canada by Fulton (1995) is used. Maps that explicitly stated the relative chronology of glacial features were used as a guide to interpret the rest of the area (e.g. Little and Ferbey, 2003; McMartin and Dredge, 2005; Smith et al., 2007; Fisher et al., 2009; Trommelen and Ross, 2010; Bednarski, 2008; Brown, 2012).

A database of retreat direction vectors was compiled using ArcGIS 10.1 (ESRI, 2012) based on glacial and surficial geology maps. The vectors are perpendicular to margin normal features, such as recessional moraines, and parallel to flutings. The vectors are parallel to the trend of eskers that were used as constraints, with consideration of regional retreat patterns. Since the density of features is variable, the map of inferred direction of retreat was converted to a regular grid using a triangulated irregular network and linear interpolation of the vectors. The vectors were first interpolated onto a $1 \mathrm{~km}$ grid, and then averaged onto a $20 \mathrm{~km}$ grid. This size was chosen as a balance between the low resolution of landforms in some areas, and to be high enough to capture lobate ice margins and where significant changes in the direction of

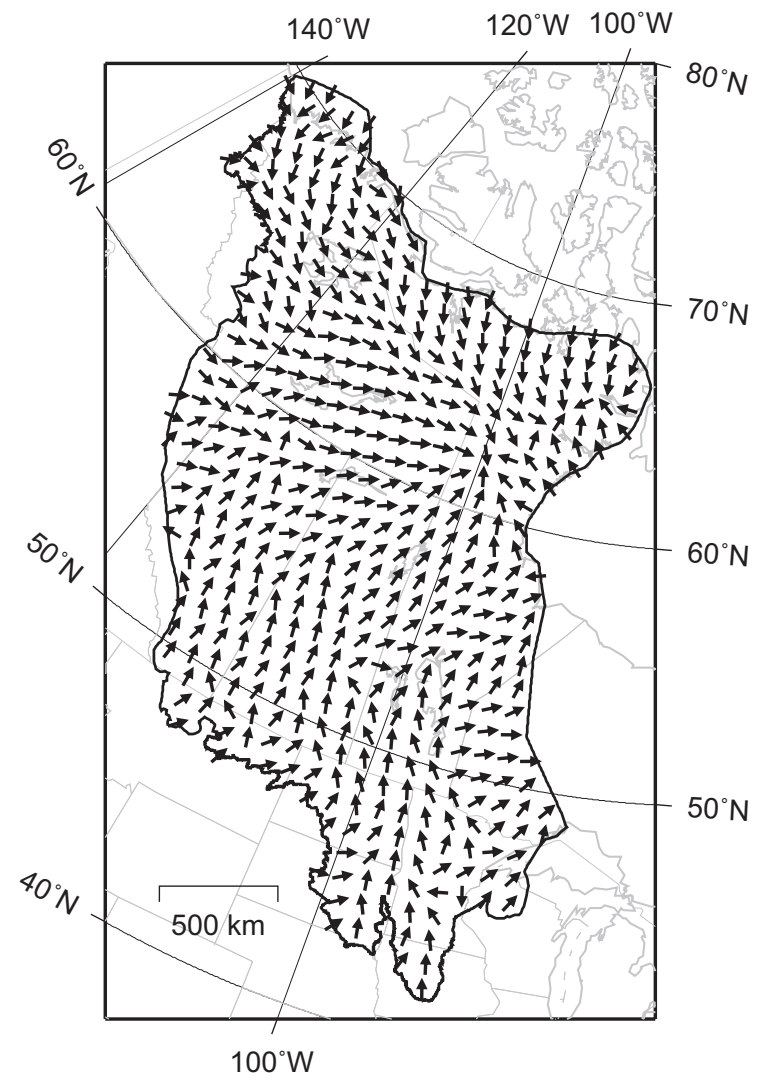

Fig. 4. Map showing the direction of retreat on a $100 \mathrm{~km}$ grid. The black outline shows the region investigated in this study.

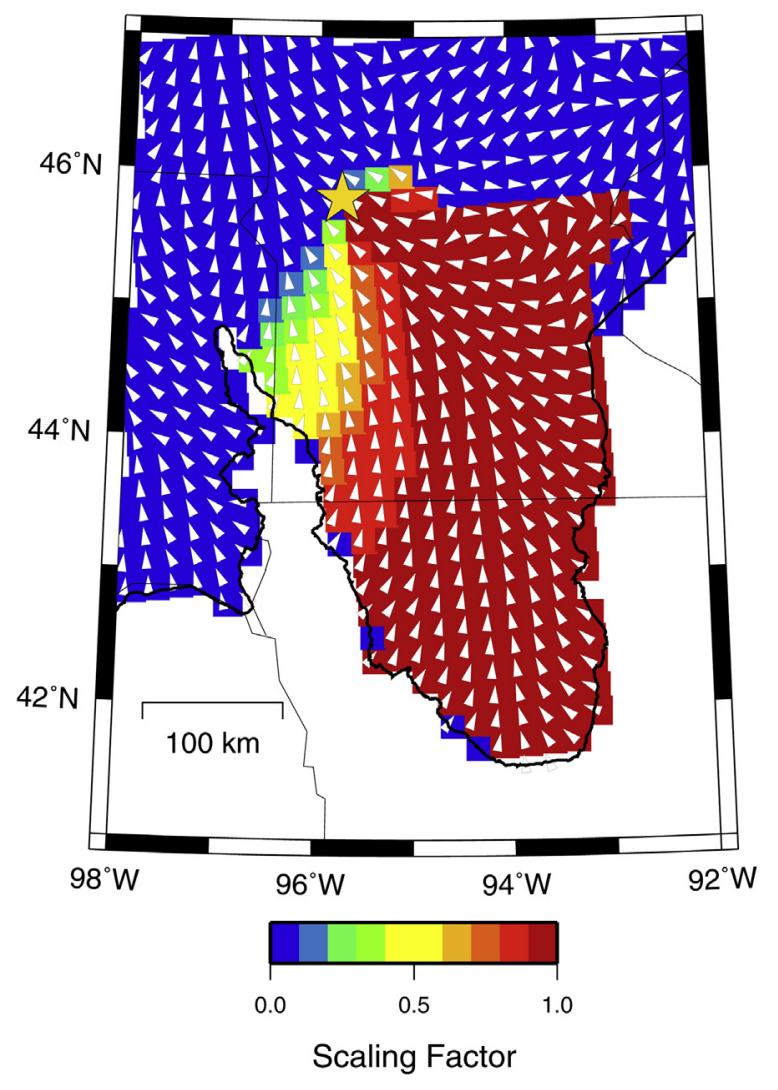

Fig. 5. Example of the scaling factor applied to a sample located at $45.789^{\circ} \mathrm{N} 95.763^{\circ} \mathrm{W}$ (gold star, ETH-32331, Lepper et al., 2007) at the northern end of the Des Moines lobe. The white arrows are the inferred direction of retreat at a grid resolution of $20 \mathrm{~km}$. The scaling factor is close to one in areas in the opposite direction of retreat, but is zero in areas glaciated by the Superior Lobe (Goebel et al., 1983).

retreat occurred. Fig. 4 shows a map of the direction of retreat at a grid resolution of $100 \mathrm{~km}^{3}$

\section{Modelling the minimum timing of ice free conditions}

A program was created in order to assess the minimum timing of retreat. The program extrapolates the probability distribution of the age of a dated sample in the direction opposite of retreat, using the assumption that the margin retreated in a time transgressive fashion (i.e. the margin retreated progressively from the Last Glacial Maximum limit to the Keewatin region). Instead of using the probability distribution to pinpoint an exact age of the sample, it is used to express increased confidence that the sample is older than a given date. For instance, if a sample has a normally distributed age of $9000 \pm 50 \mathrm{yr} \mathrm{BP}$, then at $9000 \mathrm{yr} \mathrm{BP}$ there is $50 \%$ confidence the sample is older than that, while at $9100 \mathrm{yr}$ BP the confidence is $97.8 \%$. Note that the calibrated probability distribution is generally not normally distributed, so the sum of the area under the probability curve up to the desired age is used. The probability is scaled directionally using an azimuthal $\cos ^{2}$ function until it reaches zero in the direction normal to deglaciation. The scaling function changes direction at every grid point $(20 \mathrm{~km})$ defined by the retreat map. This allows the scaling function to be broader in areas where the direction of retreat is concave (such as lobate regions). The program imposes a tolerance to stop the extrapolation if the

\footnotetext{
${ }^{3}$ A map with the $20 \mathrm{~km}$ grid is included in the Supplementary material.
} 

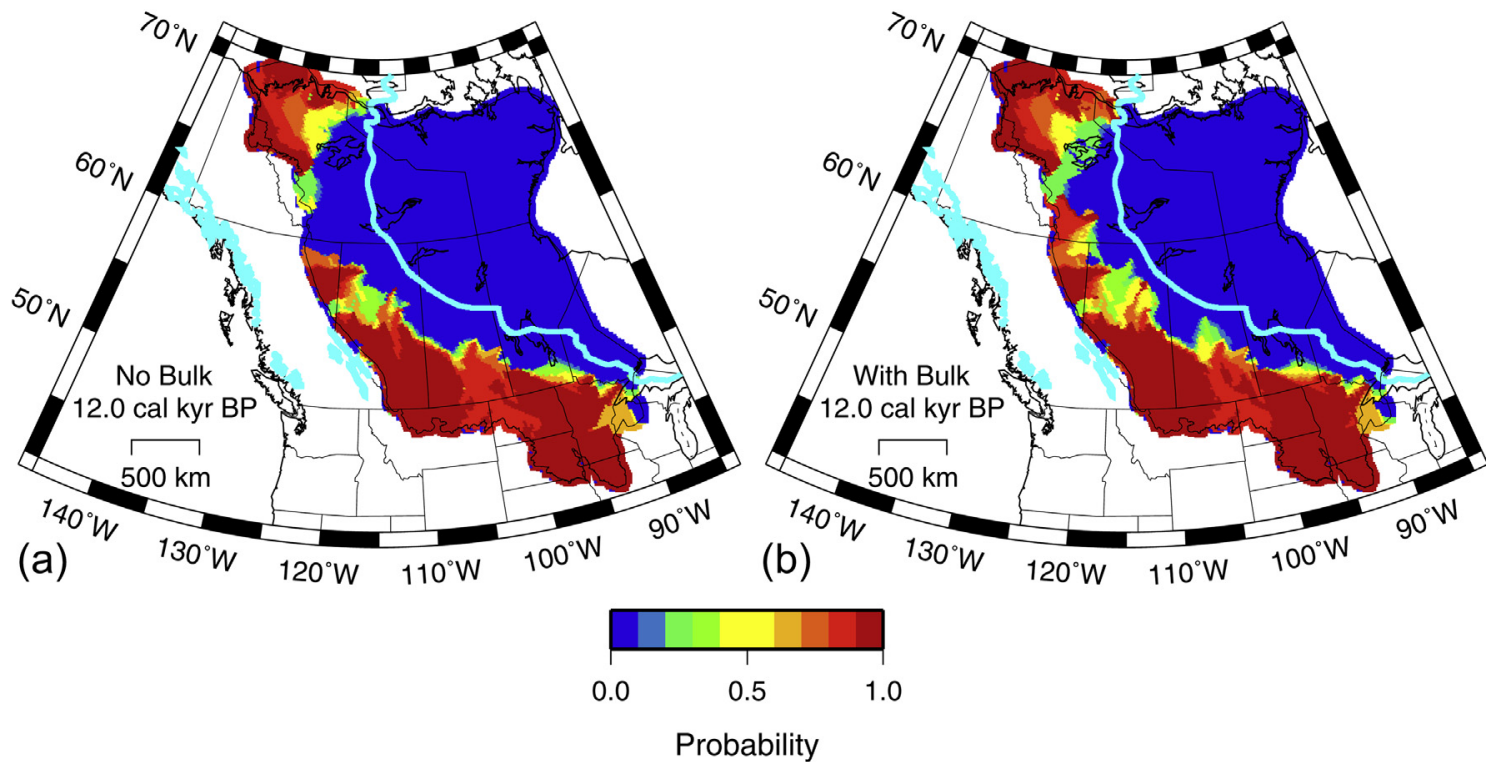

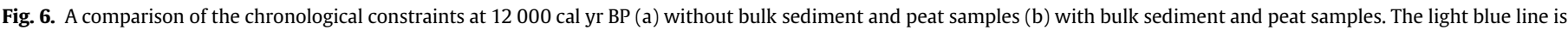

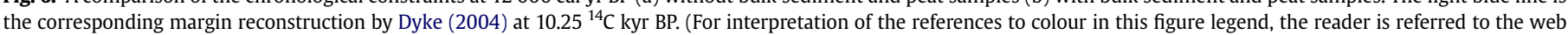
version of this article.)

direction of retreat changes by more than $25^{\circ}$ in adjacent grid points. This prevents extrapolation to areas glaciated by different sectors, such as the boundary between the Cordillera and Laurentide ice sheets. After extrapolation, the program stores the scaling factor on a $20 \mathrm{~km}$ grid. An example of the scaling function is shown on Fig. 5. The probability at each grid point is the sum of the age distribution of the sample up to the time of interest, multiplied by the scaling factor. For radiocarbon dates, the calibrated distribution determined by OxCal was used, while a scaled error function was used to calculated the probability of surface exposure and luminescence samples. At each grid point, the maximum value for all samples is taken as the confidence of ice free conditions.

\section{Comparison of the model with bulk dates}

Fig. 6 shows a comparison of the results with and without using bulk sediment and peat samples at 12000 cal yr BP, corresponding to a period within the Younger Dryas. Drainage of glacial lakes located in the western Laurentide ice sheet has been suggested as being one of the factors for causing and maintaining this cold period (e.g. Tarasov and Peltier, 2005; Condron and Winsor, 2012; Not and Hillaire-Marcel, 2012). Murton et al. (2010) suggested that Lake Agassiz could be a possible source of this water, though investigations of the northwestern outlet by Fisher et al. (2009) and Fisher and Lowell (2012) cast doubt that the it was available before the late Younger Dryas. A sample of lake sediment northwest of Great Slave Lake (GSC-3524, 12 60012100 cal yr BP, MacDonald, 1987) has a large impact on the model and, if accepted, indicates that it is certain the area between the Laurentide Ice Sheet and the Cordillera is ice free at this time. As previously discussed, lake sediment samples can be contaminated by hardwater effects and old carbon, and could potentially give an age that is older than the true age. If this sample is rejected on this basis, the oldest dates from this region include a bison bone with an age of 11 300-10 300 cal yr BP (I-9997, Harington, 2003), and wood with an age of $10400-$ 9300 cal yr BP (AECV-915C, Smith, 1992), both of which postdate the Younger Dryas. Though there have been recently published dates related to the opening of the northwest outlet of Lake Agassiz (i.e. Fisher et al., 2009), there are still few constraints between the outlet and the Arctic Ocean, even with the inclusion of bulk dates. This is especially true in areas where the density of data is low, such as the area north of $60^{\circ} \mathrm{N} .{ }^{4}$ The minimum timing of retreat of the region between the northwestern outlet of Lake Agassiz and the Arctic Ocean significantly postdates the start of the Younger Dryas when bulk sediment dates are excluded, and less so when they are included.

\section{Minimum timing of ice free conditions}

Maps of the modelled minimum timing of retreat are shown for the time intervals used by Dyke (2004) to compare the certainty of ice free conditions with the inferred margin position (Figs. 7-9). Dyke (2004) used 500 year intervals in radiocarbon years before present, and the actual timing in calendar years can be variable depending on how they are calibrated. To convert the margin model to calendar years, an error of 250 years at $1 \sigma$ (half of the 500 year interval) is applied before calibration. The age used in the maps is the median calibrated age, rounded to the nearest 100 years. The following section highlights specific samples that have the most impact on the model.

\subsection{Oldest dates constraining the minimum timing of retreat}

The southwestern margin of the Laurentide ice sheet was marked by convergence with the Cordillera ice sheet (Dyke and Prest, 1987; Dyke, 2004). The oldest radiocarbon date from terrestrial material that postdates deglaciation in southwestern Alberta is a sample of wood, which has an age of 21 700-17 $100 \mathrm{cal}$ yr BP (TO-5190, Beierle and Smith, 1998). This sample lies in an area covered by till of Cordilleran origin (Bayrock and Reimchen, 1980),

\footnotetext{
${ }^{4}$ See Supplementary material for maps comparing models with and without bulk dates at 500 year intervals.
} 

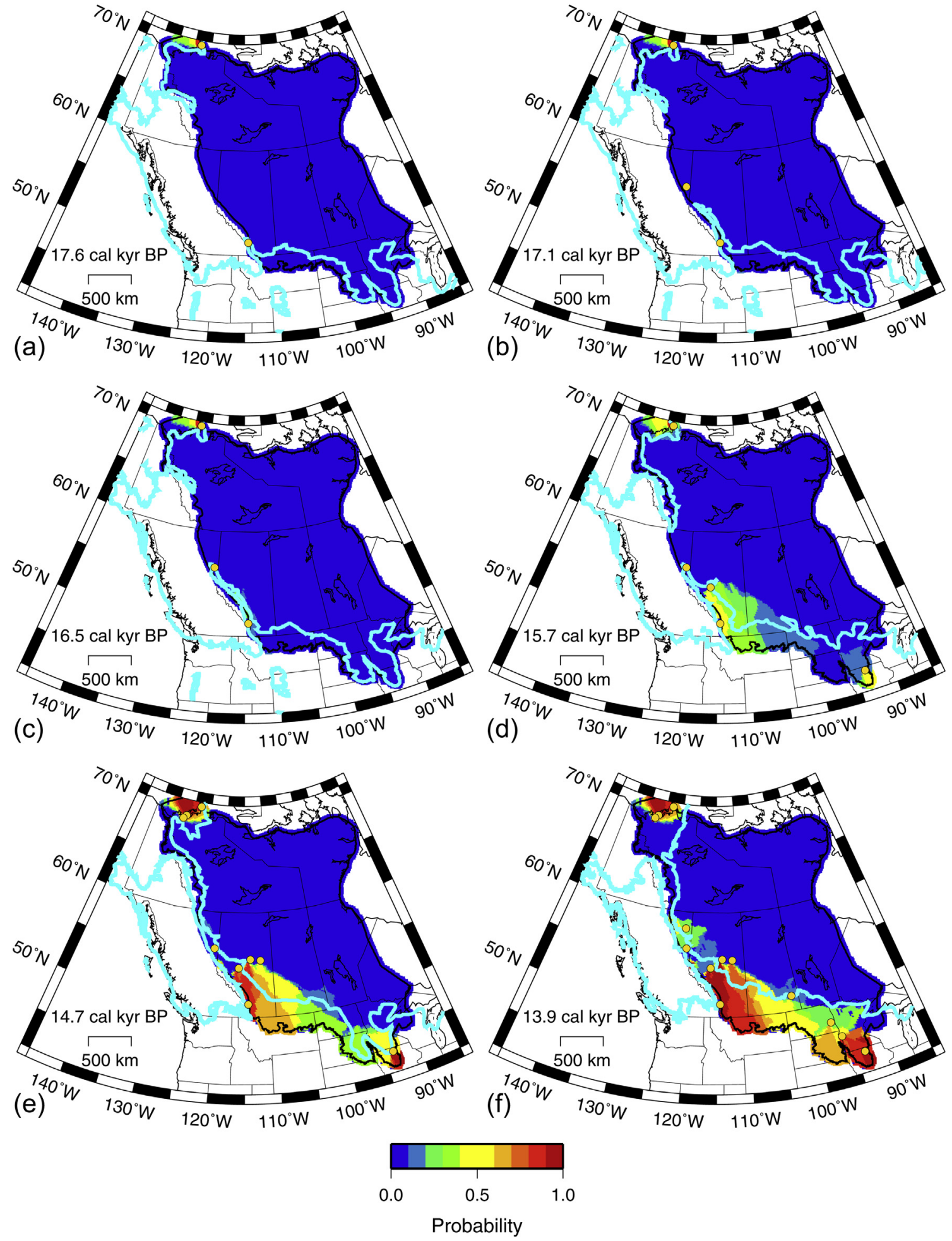

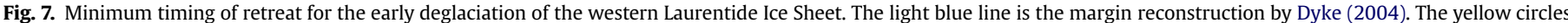

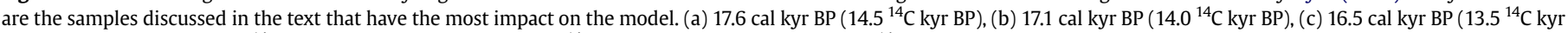

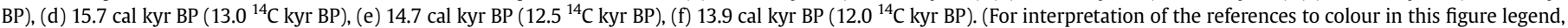
the reader is referred to the web version of this article.)

and indicates the end of convergence between the Laurentide and Cordilleran ice sheets at this latitude. Several surface exposure ${ }^{36} \mathrm{Cl}$ dates from the Foothills erratics train, which is near the confluence of the Cordillera and Laurentide ice sheets, are older than $15 \mathrm{ka}$ (Jackson et al., 1997, 1999, 2011). The large range in ages from these boulders (28-11 ka) makes it difficult to use these to constrain the minimum timing of deglaciation. The oldest radiocarbon date that overlies Laurentide deposits is a sample of wood from northeastern British Columbia (TO-2742, 17 600-16 800 cal yr BP, Catto et al., 1996). 

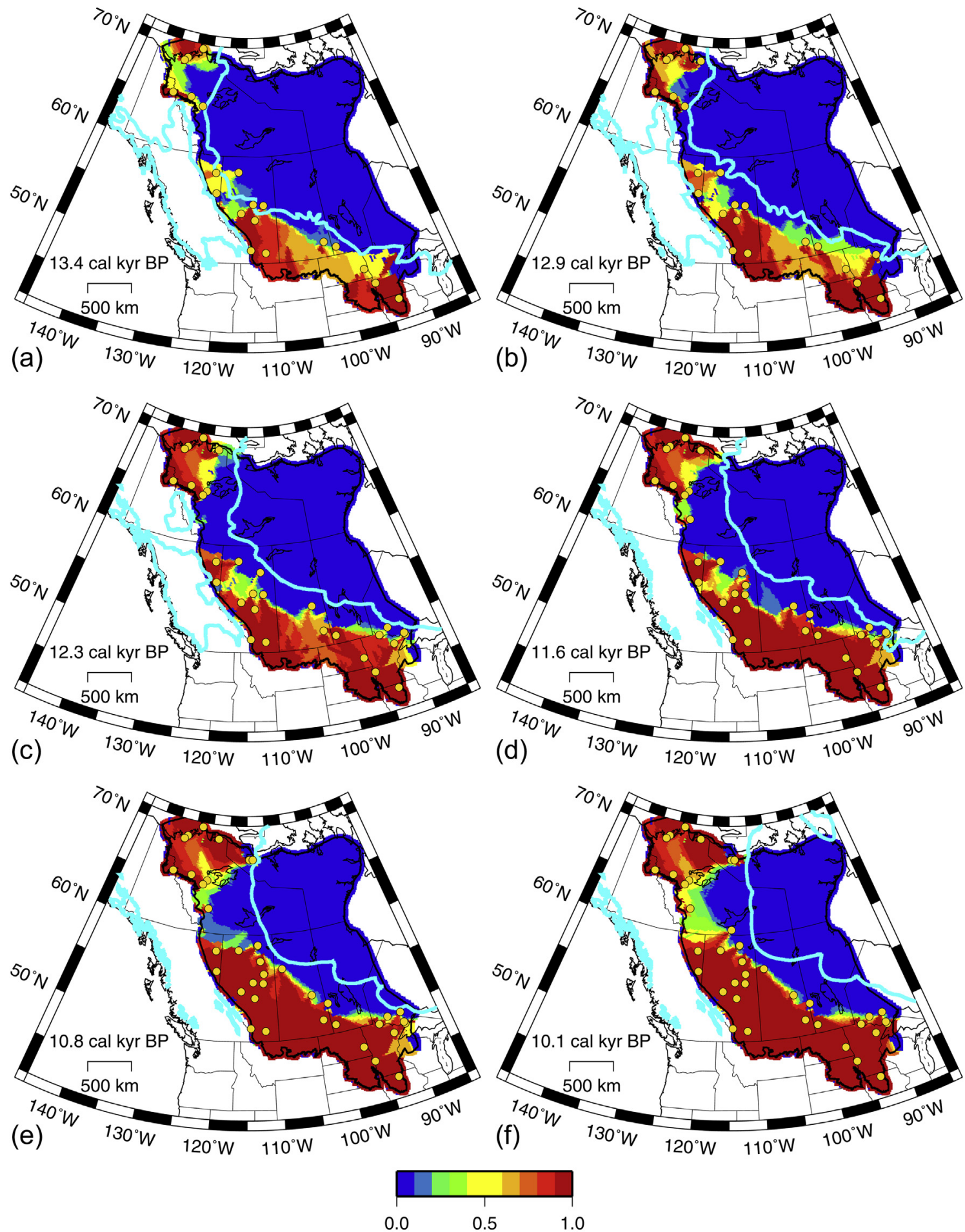

Probability

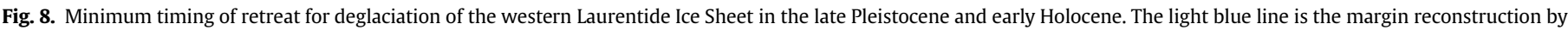

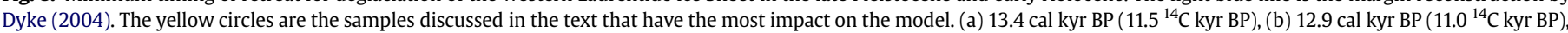

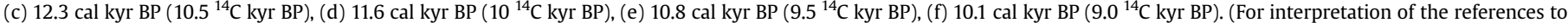
colour in this figure legend, the reader is referred to the web version of this article.)

In the Dakotas, Minnesota and Iowa, the maximum extent of the Laurentide Ice Sheet was attained by the James and Des Moines lobes (Fig. 1, Clayton and Moran, 1982). The glacial history of this region is complicated, reflecting the dynamic nature of the southern margin of the Laurentide Ice Sheet. The minimum timing of deglaciation of the Des Moines lobe from its maximum extent is from a wood sample, which has an age of 16 600-14 600 cal yr BP (W-626, Ruhe, 1969). There are no available deglacial terrestrial organic dates within the southern limits of the James Lobe, but a wood sample from below till near the southernmost extent has an 

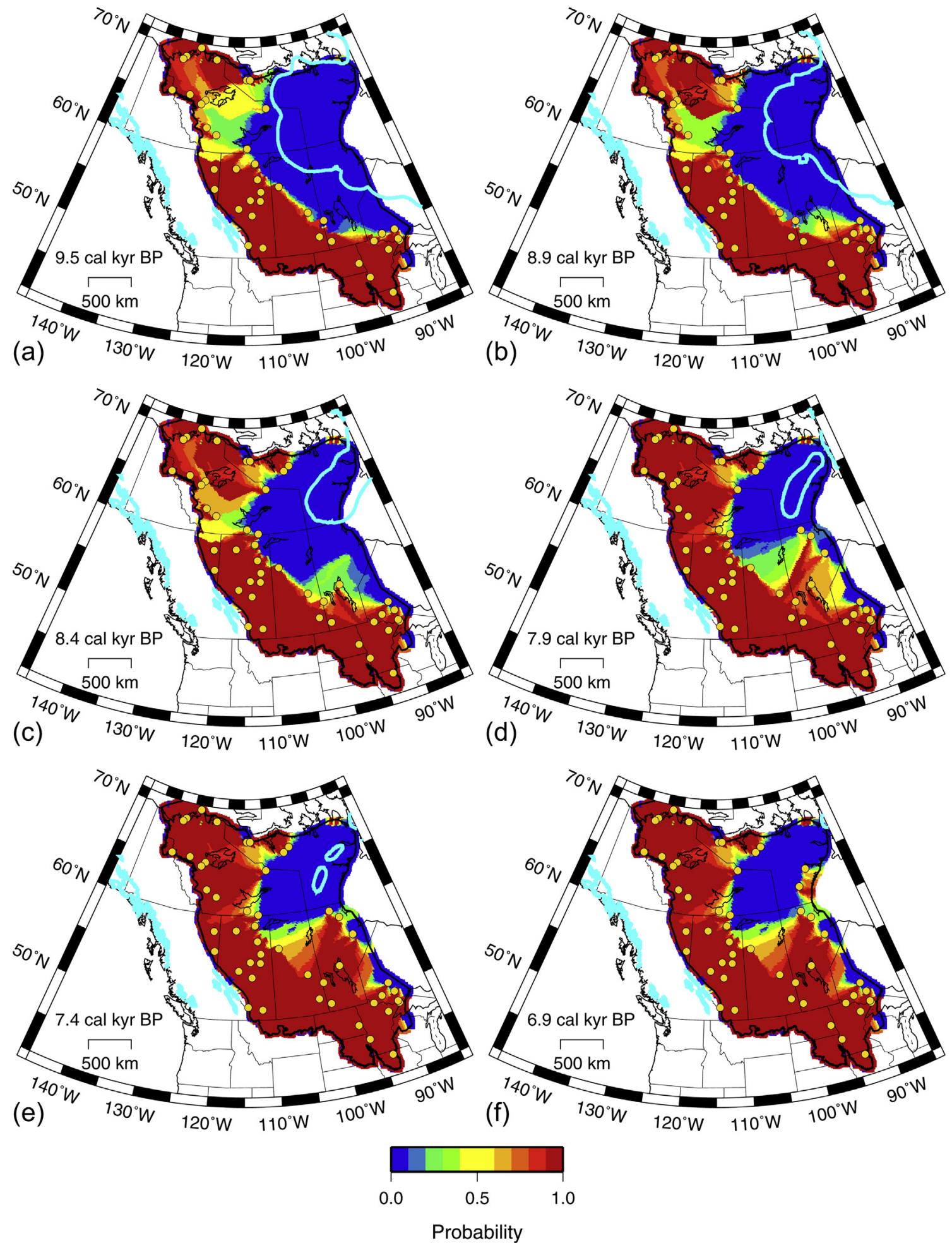

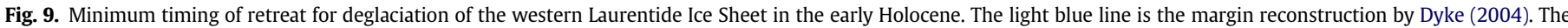

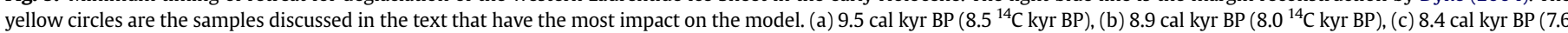

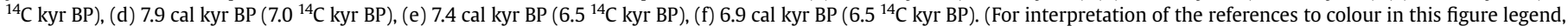
the reader is referred to the web version of this article.)

age of 15 400-14 000 cal yr BP (Johnson and McCormick, 2005), indicating the maximum position may have been attained after the Des Moines Lobe.

In the northwestern Laurentide Ice Sheet, luminescence dates from sand that predates the last advance of the ice sheet have ages between 22000 and 16000 yr BP (Murton et al., 2007; Murton, 2009). A saiga antelope bone from the Mackenzie Lowlands region that has an age of 18 600-17 700 cal yr BP (Beta-25119, Harington and Cinq-Mars, 1995) may postdate glaciation, though the stratigraphic context of the sample was not clear. The next 
oldest dates are from grass samples in ice-proximal outwash, with ages of 16 400-15 200 and 16 200-15 100 cal yr BP (GSC-1995 and GSC-1784-2, Rampton, 1988).

\subsection{Early retreat - 15000 to 13000 cal yr BP}

By 15000 cal yr BP, there is reasonable confidence that most of southern Alberta was free of ice, as indicated by luminescence dates from post-glacial sand dunes (Fig. 7, Wolfe et al., 2004; Munyikwa et al., 2011). Several dates from central Alberta have an impact on the model have ages of $15.7 \pm 1.6 \mathrm{ka}$ (SFU-O-275, Wolfe et al., 2004), $15.4 \pm 1.1$ ka (USU-524, Munyikwa et al., 2011) and $14.7 \pm 1.6$ ka (USU-524, Munyikwa et al., 2011). The oldest radiocarbon dates from southern and central Alberta are from a bison bone with an age of 13 800-13 200 cal yr BP (AECV-1203C Burns, 1996) and a horse bone with an age of 13 800-13 200 cal yr BP (OxA-14273 Burns, 2010). Luminescence dates from northeastern British Columbia and northwestern Alberta indicate ice free conditions by about $13000 \mathrm{cal}$ yr BP (13.9 $\pm 1.2 \mathrm{ka}$, SUV05309, and $13.4 \pm 1.2 \mathrm{ka}$, SAW05-01 Wolfe et al., 2007).

The Des Moines and James lobes are certain to have retreated north of the North and South Dakota border by 14000 cal yr BP (Fig. 7). Luminescence dates on sand from the Herman strandline of Lake Agassiz give an average age of $14.0 \pm 0.3 \mathrm{ka}$ (Lepper et al., 2007, 2011). Radiocarbon dates on wood from this region (e.g ETH-32334, 14 500-13 800 cal yr BP, Lepper et al., 2011) support that areas south of $46^{\circ} \mathrm{N}$ were ice free. Terrestrial samples from southern Manitoba and Saskatchewan indicate ice free conditions existed north of the US-Canada border by 13000 cal yr BP (GSC1081, 13 900-13 100 cal yr BP Lowdon et al., 1971; S-553, 14 90013500 cal yr BP, Christiansen, 1979).

By 13000 cal yr BP, northwestern mainland Northwest Territories and northern Yukon are certain to be ice free (Fig. 7). Terrestrial radiocarbon dates in Yukon near the maximum limit of glaciation indicate that retreat began before 13 800-13 $400 \mathrm{cal}$ yr BP. (GSC-2745, 13 800-13 400 cal yr BP, McNeely, 1989; OxA-18549, 13 800-13 500 cal yr BP, Zazula et al., 2009). There are several dates on wood from the Mackenzie River southwest of Fort Good Hope with ages greater than 13000 cal yr BP, the oldest being 13 80013400 (TO-1190) and 13 800-13 100 (I-15020) (Smith, 1992). A sample of Hiatella arctica east of the Mackenzie Delta on the northern coast of mainland Northwest Territories has an age of 13 700-12 900 cal yr BP (AECV-643Cc, McNeely and Jorgensen, 1992).

\subsection{Younger Dryas - 13000 to 11500 cal yr BP}

Determining the chronology of potential northwest and eastern drainage routes of Lake Agassiz has been the focus of several recent studies (i.e. Teller et al., 2005; Lowell et al., 2005, 2009; Fisher et al., 2009), and several samples from these areas date to the Younger Dryas period (Fig. 8). The area near Lake Superior in northeastern Minnesota is certain to be ice free during the Younger Dryas, based on dates on wood (ETH-28939, 12 600-12 200 cal yr BP and ETH31429, 12 600-11 800, Lowell et al., 2009; TO-1504, 13 20012100 cal yr BP, Bajc et al., 2000; W-827, 14 000-12 600 cal yr BP, Wright and Watts, 1969). Ice also had retreated north of the Minnesota-Ontario border, as indicated by a wood sample (ETH32339, 12 600-12 100 cal yr BP, Lowell et al., 2009). In the vicinity of the northwestern drainage route in Alberta, there are two terrestrial samples that provide a minimum timing of retreat during the Younger Dryas (ETH-30586, 12 600-12 $100 \mathrm{cal}$ yr BP and ETH-32165, 12 400-11 800 cal yr BP, Fisher et al., 2009). Other dates from this period in the Prairies include a bison bone from western Manitoba (BGS-617, 12 600-11 400 cal yr BP, Nielsen et al., 1984) and wood from central Saskatchewan (S-3271, 13 500-11 500 cal yr BP, Christiansen et al., 1995). In the Northwest Territories, wood samples (AECV-917C, 12 600-11 400 cal yr BP, Smith, 1992; 13 000-12 600 cal yr BP, GSC-6805, Dyke et al., 2003) indicate that much of the region occupied by glacial Lake Mackenzie was ice free during the Younger Dryas.

\subsection{Early Holocene - 11500 to 10000 cal yr BP}

There are a few samples that impact the minimum timing of retreat model in the early Holocene (Fig. 8). Several marine shell dates from northwestern mainland Nunavut are from this period, with the oldest ages of 11 500-10 800 cal yr BP (GSC-5999, McNeely, 2006) and 11 700-11 100 cal yr BP (GSC-6081, Dredge et al., 1999). A luminescence date south of Great Slave Lake has an age of $10.5 \pm 0.5 \mathrm{ka}$ (SFU-O-159 Wolfe et al., 2004). There are several dates from northeastern Alberta that are early Holocene in age, but the samples that impact the model the most are two wood samples from a delta that formed in glacial Lake McConnell, with ages of 11 400-11 200 cal yr BP (WAT-2661 and WAT-2662, Smith, 1994). In western Saskatchewan the most significant date is a sample of plant macrofossils that has an age of 11 700-11300 cal yr BP (UCIAMS-34698, Anderson, 2012). A sample of wood from northwest of Lake Superior with an age of 11 600-10 700 cal yr BP (ETH-31001, Lowell et al., 2009) impacts the model in the area north of the Ontario-Minnesota border.

\section{5. $10000-8000$ cal yr BP}

A few samples during the period between 10000 and $8000 \mathrm{cal}$ yr BP significantly increase the area constrained to be ice free (Fig. 9). Twigs from an ice contact deposit with an age of $10000-$ 9200 cal yr BP (TO-4241, Dredge et al., 1999) provide the minimum timing of retreat for a large region between Great Bear Lake and north of Great Slave Lake. A wood sample with an age $10400-$ 9300 cal yr BP (AECV-915C, Smith, 1992) indicates that southeastern glacial Lake Mackenzie was ice free. A twig (TO-7868, Seppä et al., 2003) and marine shell dates (GSC-110-2, Lowdon and Blake, 1968 ) indicate that the region southeast of Bathurst Inlet in Nunavut was ice free by $9000-8400$ cal yr BP. Several wood samples from glacial Lake McConnell near the town of Fort Smith, Northwest Territories, date to this period, the oldest having an age of 9500-8700 cal yr BP (I-14568, Smith, 1994). Twigs from central Manitoba have an age of 8600-8400 cal yr BP(CAMS-32189 Morlan et al., 2000). Two marine shell samples with ages of 9000-7600 cal yr BP (BGS-813, Nielsen et al., 1986) and 8400-7900 cal yr BP (GSC3070, Morlan et al., 2000) constrain the minimum timing of retreat to northern Manitoba. A charcoal sample from western Ontario has an age of 9400-8800 cal yr BP (Beta-111667, Dyke et al., 2003).

\subsection{Final stages of glaciation $-8000-6000$ cal yr BP}

There are seven samples that are relevant to the minimum timing of retreat from 8000 to $6000 \mathrm{cal} \mathrm{yr} \mathrm{BP} \mathrm{(Fig.} \mathrm{9).} \mathrm{A} \mathrm{woody} \mathrm{scale}$ from northern Manitoba has an age of 8200-7600 cal yr BP (CAMS109288, Camill et al., 2012). Two marine shells from west of Hudson Bay in Nunavut have ages of 7400-6900 cal yr BP (GSC-5234, McNeely and Atkinson, 1995) and 7200-6700 cal yr BP (GSC-2042, McNeely and Brennan, 2005). In northeastern mainland Nunavut, a marine shell date has an age of 6400-6000 cal yr BP (GSC-6839, Dredge and McMartin, 2005). There are three dates west of the Keewatin sector divide including marine shells with ages of 68006300 and 6500-6100 cal yr BP (GSC-693, Lowdon and Blake, 1968 and GSC-6857, McMartin et al., 2006) and a sample of Salix charcoal with an age of 6400-6100 cal yr BP (GSC-2152, McNeely, 1989). 

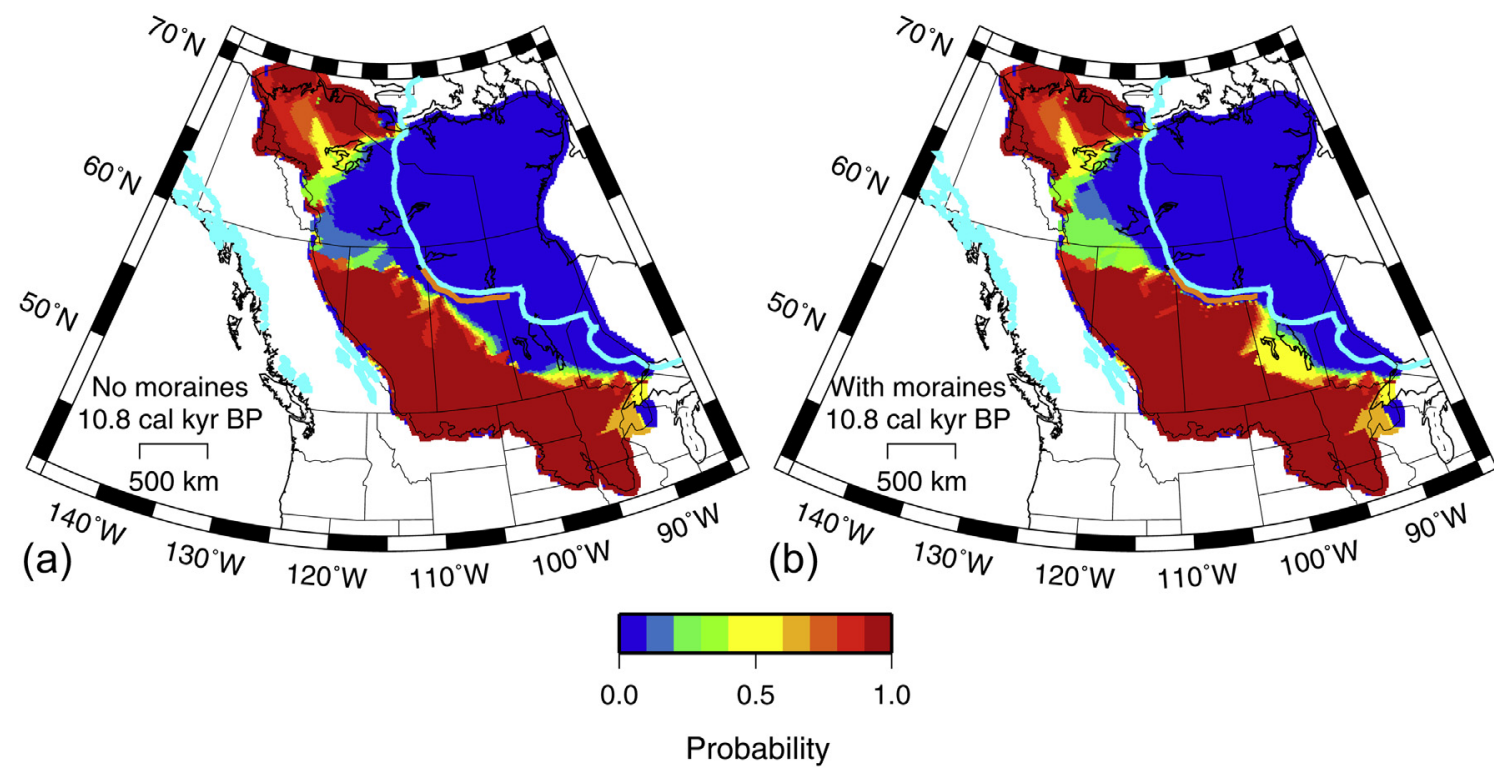

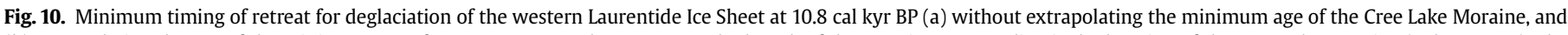

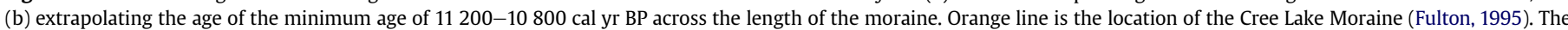

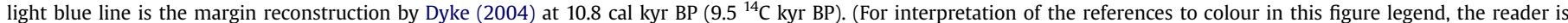
referred to the web version of this article.)

There are no samples that constrain the final timing of deglaciation for much of the Keewatin region of Nunavut.

\section{Discussion}

\subsection{Comparison with margin reconstructions}

Figs. 7-9 show the inferred margin positions of Dyke (2004) along with this study's models of the minimum timing of deglaciation. In most cases, the minimum timing of deglaciation lags the ice free areas determined by Dyke (2004). The only exceptions are in Alberta, where recently published luminescence dates indicate earlier ice free conditions. There are a few causes for the lag between margin reconstructions and the minimum timing of deglaciation. During early deglacial times, the vegetation records indicate a tundra climate (Dyke et al., 2004), so there was likely limited production of plants that could be preserved for radiocarbon dating. The delay of recolonization may not be present in all locations, as Fisher et al. (2009) suggested in the Fort McMurray area. Ice proximal lakes covered vast regions of the study area, and are often devoid of sufficient material suitable for radiocarbon dating (e.g. Risberg et al., 1999; Teller et al., 2000). Finally, the distribution of dates means that a single sample is often the only constraint on the timing of deglaciation over several hundred to thousands of $\mathrm{km}^{2}$.

Of the several hundred radiocarbon and luminescence dates used to produce the models on Figs. 7-9, only 55 have a significant impact on advancing the area constrained to be ice free based purely on absolute chronology. Additional constraints in key locations could greatly improve the model of the minimum timing of retreat. Extrapolation of constraints along broad moraines could provide the minimum timing of retreat over a wide area. For example, the Cree Lake Moraine in northern Saskatchewan (Fig. 1) has a minimum age of 11 200-10 800 cal yr BP (ETH-30175) according to Fisher et al. (2009). Fig. 10 shows the minimum timing of retreat when this age is extrapolated along its entire length at $10800 \mathrm{cal}$ yr BP. The reconstructed margin by Dyke (2004) at this time matches the boundary between where ice free conditions are certain and unknown in the model. Fig. 10 illustrates the sensitivity of the modelling technique, and how additional data would change the minimum timing of retreat. Acquisition of early dates in areas where there are few data would greatly reduce the uncertainty of the timing of deglaciation.

\subsection{Northwest drainage route of Lake Agassiz}

The timing of drainage of Lake Agassiz though northern Alberta has been the subject of many recent investigations (i.e. Lowell et al., 2005; Teller et al., 2005; Teller and Boyd, 2006; Fisher, 2007; Couch and Eyles, 2008; Fisher et al., 2009; Murton et al., 2010; Anderson, 2012; Fisher and Lowell, 2012). There is considerable debate as to when the northwest outlet was available to flow towards the Arctic Ocean, and if it was at the start, and possibly the cause of the Younger Dryas. The model of minimum timing of retreat (Fig. 9) shows that in the region between the Mackenzie Delta and the northwestern outlet of Lake Agassiz is only certain to be ice free during the early Holocene (Section 7.4). Even when bulk dates are included (Section 6), the minimum timing of retreat post-dates the start of the Younger Dryas. This does not completely eliminate the possibility that a glacial lake drained from the southwestern part of the ice sheet in the early Younger Dryas to account for the erosional event observed in the Mackenzie Delta by Murton et al. (2010), as there are few data between the two locations. The geomorphic and chronological evidence presented by Fisher et al. (2009) and Fisher and Lowell (2012) indicates that it was unlikely to be Lake Agassiz.

\section{Conclusions}

This study presents an assessment of the minimum timing of ice free conditions in the area covered by the western Laurentide Ice Sheet using previously published radiocarbon and luminescence dates. A map of the direction of retreat was constructed using geomorphic features, such as moraines, streamlined landforms and eskers. The direction of retreat was used to extrapolate chronological constraints to determine when areas were certain to be ice free. The model shows that there is a deficiency of data for large 
regions, with 55 samples identified as providing the greatest influence on the model. In many areas, the margin chronology reconstructed by Dyke and Prest (1987) and Dyke (2004) is up to several hundred kilometres from the nearest constraint. This is most evident in areas north of $60^{\circ} \mathrm{N}$, where there a single data point can be the only constraint over large regions. Some areas with a high density of significant dates include the area west of Lake Superior, central Alberta, and the glacial Lake Mackenzie basin. Excluding radiocarbon dates of questionable material makes the minimum timing of retreat over 1000 years younger in some locations. This has potential implications for ice sheet modelling, as early retreat from a region could cause ice volume to be underestimated, and impact the timing of meltwater when entered the ocean. Considering the contributions of the western Laurentide Ice Sheet to sea level change and the proposed impacts of its retreat on global climate during the late Pleistocene and early Holocene, there is a need for focused studies in areas identified by the model to improve understanding of retreat history.

\section{Acknowledgements}

Funding for this research was provided by ANU PhD and International Postgraduate Research scholarships. I thank my supervisor Paul Tregoning and my supervisory panel of Anthony Purcell, Kurt Lambeck and Thomas James for their support and feedback on this work. My gratitude goes to A.S. Dyke for sending me an updated version of his radiocarbon date database and Michelle Trommelen for sending me a preliminary database of glacial features for Manitoba. I appreciate discussions with Stewart Fallon and Rachel Wood on radiocarbon dating. Comments by Timothy Fisher, Rod Smith and an anonymous reviewer led to substantial improvements of this paper.

\section{Appendix A. Supplementary data}

Supplementary data related to this article can be found at http:// dx.doi.org/10.1016/j.quascirev.2013.06.001.

\section{References}

Abbott, M.B., Stafford, T.W., 1996. Radiocarbon geochemistry of modern and ancient Arctic lake systems, Baffin Island, Canada. Quaternary Research 45, 300-311.

Anderson, T., 2012. Evidence from Nipawin Bay in Frobisher Lake, Saskatchewan, for three highstand and three lowstand lake phases between 9 and 10 (10.1 and $11.5 \mathrm{cal}) \mathrm{ka}$ BP. Quaternary International 260, 66-75.

Arnold, T.G., 2002. Radiocarbon dates from the ice-free corridor. Radiocarbon 44 437-454.

Aylsworth, J.M., Shilts, W.W., 1989a. Bedforms of the Keewatin ice sheet, Canada. Sedimentary Geology 62, 407-428.

Aylsworth, J.M., Shilts, W.W., 1989b. Glacial Features Around the Keewatin Ice Divide, Northwest Territories Scale 1:1 000000.

Bajc, A., Schwert, D., Warner, B., Williams, N., 2000. A reconstruction of Moorhead and Emerson Phase environments along the eastern margin of glacial Lake Agassiz, Rainy River basin, northwestern Ontario. Canadian Journal of Earth Sciences 37, 1335-1353.

Barber, D.C., Dyke, A., Hillaire-Marcel, C., Jennings, A.E., Andrews, J.T., Kerwin, M.W. Bilodeau, G., McNeely, R., Southon, J., Morehead, M.D., Gagnon, J.M., 1999. Forcing of the cold event of 8,200 years ago by catastrophic drainage of Laurentide lakes. Nature 400, 344-348.

Bateman, M.D., Murton, J.B., 2006. The chronostratigraphy of Late Pleistocene glacial and periglacial aeolian activity in the Tuktoyaktuk Coastlands, NWT, Canada. Quaternary Science Reviews 25, 2552-2568.

Bayrock, L.A., Reimchen, T.H.F., 1980. Surficial Geology Alberta Foothills and Rocky Mountains Scale 1:250 000.

Bednarski, J.M., 2008. Landform assemblages produced by the Laurentide Ice Sheet in northeastern British Columbia and adjacent Northwest Territories - constraints on glacial lakes and patterns of ice retreat. Canadian Journal of Earth Sciences 45, 593-610.

Bednarski, J.M., Smith, I.R., 2007. Laurentide and montane glaciation along the Rocky Mountain foothills of northeastern British Columbia. Canadian Journal of Earth Sciences 44, 445-457.
Beierle, B., Smith, D.G., 1998. Severe drought in the early Holocene $(10,000-6800$ BP) interpreted from lake sediment cores, southwestern Alberta, Canada. Palaeogeography, Palaeoclimatology, Palaeoecology 140, 75-83.

Bertrand, S., Araneda, A., Vargas, P., Jana, P., Fagel, N., Urrutia, R., 2012. Using the N/C ratio to correct bulk radiocarbon ages from lake sediments: Insights from Chilean Patagonia. Quaternary Geochronology 12, 23-29.

Boulton, G.S., Smith, G.D., Jones, A.S., Newsome, J., 1985. Glacial geology and glaciology of the last mid-latitude ice sheets. Journal of the Geological Society of London 142, 447-474.

Boyd, M., 2007. Early postglacial history of the southeastern Assiniboine Delta, glacial Lake Agassiz basin. Journal of Paleolimnology 37, 313-329.

Breckenridge, A., Lowell, T.V., Fisher, T.G., Yu, S., 2012. A late Lake Minong transgression in the Lake Superior basin as documented by sediments from Fenton Lake, Ontario. Journal of Paleolimnology 47, 1-14.

Brock, F., Froese, D.G., Roberts, R.G., 2010. Low temperature (LT) combustion of sediments does not necessarily provide accurate radiocarbon ages for site chronology. Quaternary Geochronology 5, 625-630.

Brock, F., Lee, S., Housley, R.A., Bronk Ramsey, C., 2011. Variation in the radiocarbon age of different fractions of peat: a case study from Ahrenshöft, northern Germany. Quaternary Geochronology 6, 550-555.

Broecker, W.S., 2006. Was the Younger Dryas triggered by a flood? Science 312, 1146-1148.

Bronk Ramsey, C., 2009. Bayesian analysis of radiocarbon dates. Radiocarbon 51, 337-360.

Brown, V.H., 2012. Ice stream Dynamics and Pro-glacial Lake Evolution along the North-western Margin of the Laurentide Ice Sheet. Durham University. (Ph.D. thesis).

Brown, V.H., Stokes, C.R., Ò Cofaigh, C., 2011. The glacial geomorphology of the north-west sector of the Laurentide Ice Sheet. Journal of Maps 7, 409-428.

Bryson, R.A., Wendland, W.M., Ives, J.D., Andrews, J.T., 1969. Radiocarbon isochrones on the disintegration of the Laurentide Ice Sheet. Arctic and Alpine Research, 113.

Burns, J.A., 1996. Vertebrate paleontology and the alleged ice-free corridor: the meat of the matter. Quaternary International 32, 107-112.

Burns, J.A., 2010. Mammalian faunal dynamics in Late Pleistocene Alberta, Canada. Quaternary International 217, 37-42.

Camill, P., Umbanhowar, C.E., Geiss, C., Hobbs, W.O., Edlund, M.B., Shinneman, A.C., Dorale, J.A., Lynch, J., 2012. Holocene climate change and landscape development from a low-Arctic tundra lake in the western Hudson Bay region of Manitoba, Canada. Journal of Paleolimnology, 1-18.

Catto, N., Liverman, D.G., Bobrowsky, P.T., Rutter, N., 1996. Laurentide, Cordilleran, and montane glaciation in the western Peace River-Grande prairie region, Alberta and British Columbia, Canada. Quaternary International 32, 21-32.

Christiansen, E.A., 1979. The Wisconsinan deglaciation, of southern Saskatchewan and adjacent areas. Canadian Journal of Earth Sciences 16, 913-938.

Christiansen, E.A., Sauer, E.K., Schreiner, B.T., 1995. Glacial Lake Saskatchewan and Lake Agassiz deltas in east-central Saskatchewan with special emphasis on the Nipawin delta. Canadian Journal of Earth Sciences 32, 334-348.

Clark, P.U., Dyke, A.S., Shakun, J.D., Carlson, A.E., Clark, J., Wohlfarth, B., Mitrovica, J.X., Hostetler, S.W., McCabe, A.M., 2009. The Last Glacial Maximum. Science 325, 710-714

Clark, P.U., Walder, J.S., 1994. Subglacial drainage, eskers, and deforming beds beneath the Laurentide and Eurasian ice sheets. Geological Society of America Bulletin 106, 304-314.

Clayton, L., Moran, S.R., 1982. Chronology of late Wisconsinan glaciation in middle North America. Quaternary Science Reviews 1, 55-82.

Condron, A., Winsor, P., 2012. Meltwater routing and the Younger Dryas. Proceedings of the National Academy of Sciences 109, 19928-19933.

Couch, A.G., Eyles, N., 2008. Sedimentary record of glacial Lake Mackenzie, Northwest Territories, Canada: implications for Arctic freshwater forcing. Palaeogeography, Palaeoclimatology, Palaeoecology 268, 26-38.

Coulthard, R.D., Furze, M.F., Piekowski, A.J., Nixon, C., England, J.H., 2010. New marine $\Delta \mathrm{R}$ values for Arctic Canada. Quaternary Geochronology 5, 419-434.

Davis, N.K., Locke III, W.W., Pierce, K.L., Finkel, R.C., 2006. Glacial Lake Musselshell: Late Wisconsin slackwater on the Laurentide ice margin in central Montana, USA. Geomorphology 75, 330-345.

Deevey, E.S., Gross, M.S., Hutchinson, G.E., Kraybill, H.L., 1954. The natural C14 contents of materials from hard-water lakes. Proceedings of the National Academy of Sciences of the United States of America 40, 285.

Dredge, L.A., Kerr, D.E., Wolfe, S.A., 1999. Surficial materials and related ground ice conditions, Slave Province, NWT, Canada. Canadian Journal of Earth Sciences 36, 1227-1238.

Dredge, L.A., McMartin, I., 2005. Postglacial marine deposits and marine limit determinations, inner Wager Bay area, Kivalliq region, Nunavut. Current Research. 2005-B3.

Duk-Rodkin, A., Barendregt, R.W., Tarnocai, C., Phillips, F.M., 1996. Late Tertiary to late Quaternary record in the Mackenzie Mountains, Northwest Territories, Canada: stratigraphy, paleosols, paleomagnetism, and chlorine-36. Canadian Journal of Earth Sciences 33, 875-895.

Dyke, A., Moore, A., Robertson, L., 2003. Deglaciation of North America. Open File 1574. Geological Survey of Canada.

Dyke, A.S., 2004. An outline of North American deglaciation with emphasis on central and northern Canada. In: Ehlers, J., Gibbard, P.L. (Eds.), Quaternary Glaciations-extent and Chronology - Part II: North America, Developments in Quaternary Science. Elsevier, pp. 373-424. 
Dyke, A.S., Giroux, D., Robertson, L., 2004. Paleovegetation Maps of Northern North America, 18000 to 1000 BP. Open File 4682. Geological Survey of Canada.

Dyke, A.S., Prest, V.K., 1987. Late Wisconsinan and Holocene history of the Laurentide ice sheet. Géographie physique et Quaternaire 41, 237-263.

England, J., Dyke, A.S., Coulthard, R.D., Mcneely, R., Aitken, A., 2013. The exaggerated radiocarbon age of deposit-feeding molluscs in calcareous environments. Boreas 42.

Evans, D.J.A., Clark, C.D., Rea, B.R., 2008. Landform and sediment imprints of fast glacier flow in the southwest Laurentide Ice Sheet. Journal of Quaternary Science 23, 249-272.

Fisher, T.G., 2007. Abandonment chronology of glacial Lake Agassiz's northwestern outlet. Palaeogeography, Palaeoclimatology, Palaeoecology 246, 31-44.

Fisher, T.G., Lowell, T.V., 2012. Testing northwest drainage from Lake Agassiz using extant ice margin and strandline data. Quaternary International 260, 106-114.

Fisher, T.G., Smith, D.G., Andrews, J.T., 2002. Preboreal oscillation caused by a glacial Lake Agassiz flood. Quaternary Science Reviews 21, 873-878.

Fisher, T.G., Waterson, N., Lowell, T.V., Hajdas, I., 2009. Deglaciation ages and meltwater routing in the Fort McMurray region, northeastern Alberta and northwestern Saskatchewan, Canada. Quaternary Science Reviews 28, 16081624

Fisher, T.G., Yansa, C.H., Lowell, T.V., Lepper, K., Hajdas, I., Ashworth, A., 2008. The chronology, climate, and confusion of the Moorhead Phase of glacial Lake Agassiz: new results from the Ojata Beach, North Dakota, USA. Quaternary Science Reviews 27, 1124-1135.

Forman, S.L., Pierson, J., Lepper, K., 2000. Luminescence geochronology. In: Quaternary Geochronology: Methods and Applications. American Geophysical Union, Washington, pp. 157-176.

Fullerton, D.S., Bluemle, J.P., Clayton, L., Steece, F.V., Tipton, M.J., Bretz, R., Goebel, J.E., 1995. Quaternary Geologic Map of the Dakotas 4 Degrees X 6 Degrees Quadrangle, United States. USGS Numbered Series I-1420(NL-14). U.S. Geological Survey. Scale 1:1,000,000.

Fullerton, D.S., Christiansen, E.A., Schreiner, B.T., Colton, R.B., Clayton, L., 2007. Quaternary Geologic Map of the Regina 4 Degrees X 6 Degrees Quadrangle, United States and Canada. USGS Numbered Series I-1420(NM-13). U.S. Geological Survey. Scale 1:1,000,000.

Fullerton, D.S., Colton, R.B., Bush, C.A., Straub, A.W., 2004. Map Showing Spatial and Temporal Relations of Mountain and Continental Glaciations on the Northern Plains, Primarily in Northern Montana and Northwestern North Dakota. In: Scientific Investigations Map 2843. United States Geological Survey, 1 map.

Fullerton, D.S., Ringrose, S.M., Clayton, L., Schreiner, B.T., Goebel, J.E., 2000. Quaternary Geologic Map of the Winnipeg 4 Degrees X 6 Degrees Quadrangle, United States and Canada. USGS Numbered Series I-1420(NM-14). U.S. Geological Survey. Scale 1:1,000,000.

Fulton, R.J., 1995. Surficial Materials of Canada. Map 1880A. Geological Survey of Canada. Scale 1:5000 000.

Fulton, R.J., Blais-Stevens, A., Sun, C., Eilers, R.G., Betcher, R., Elson, J.A., Veldhuis, H., Fraser, W.R., 2004. Surficial materials of the Virden area, Manitoba and Saskatchewan. Geological Survey of Canada, Bulletin 546, 104.

Goebel, J.E., Mickelson, D.M., Farrand, W.R., Clayton, L., Knox, J.C., Cahow, A. Hobbs, H.C., Walton Jr., M.S., 1983. Quaternary Geologic Map of the Minneapolis 4 Degrees X 6 Degrees Quadrangle, United States. USGS Numbered Series I1420(NL-15). U.S. Geological Survey. Scale 1:1,000,000.

Gosse, J.C., Phillips, F.M., 2001. Terrestrial in situ cosmogenic nuclides: theory and application. Quaternary Science Reviews 20,1475-1560.

Gregoire, L.J., Payne, A.J., Valdes, P.J., 2012. Deglacial rapid sea level rises caused by ice-sheet saddle collapses. Nature 487, 219-222.

Grimm, E.C., Maher Jr., L.J., Nelson, D.M., 2009. The magnitude of error in conventional bulk-sediment radiocarbon dates from central North America. Quaternary Research 72, 301-308.

Hallberg, G.R., Lineback, J.A., Mickelson, D.M., Knox, J.C., Goebel, J.E., Hobbs, H.C., Whitfield, J.W., Ward, R.A., Boellstorff, J.D., Swinehart, J.B., Dreeszen, V.H., 1994 Quaternary Geologic Map of the Des Moines 4 Degrees X 6 Degrees Quadrangle, United States. USGS Numbered Series I-1420(NK-15). U.S. Geological Survey. Scale $1: 1,000,000$.

Hanson, M., Campbell, J.E., Smith, J.S., Slimmon, W.L., 2011. Saskatchewan Ice-flow Indicator Mapping Project: Preliminary Report. Miscellaneous Report 20114.2, Paper A-11. Saskatchewan Geological Survey, Saskatchewan Ministry of Energy and Resources.

Harington, C., 2003. Annotated Bibliography of Quaternary Vertebrates of Northern North America - with Radiocarbon Dates. University of Toronto Press.

Harington, C., Cinq-Mars, J., 1995. Radiocarbon dates on saiga antelope (Saiga tatarica) fossils from Yukon and the Northwest Territories. Arctic 48, 1-7.

Huntley, D., Mills, A., Paulen, R., 2008. Surficial deposits, landforms, glacial history, and reconnaissance drift sampling in the Trout Lake map area, Northwest Territories. Current Research, 2008-14. Geological Survey of Canada, 14p.

Hutchinson, I., James, T.S., Reimer, P.J., Bornhold, B.D., Clague, J.., 2004. Marine and limnic radiocarbon reservoir corrections for studies of late- and postglacial environments in Georgia Basin and Puget Lowland, British Columbia, Canada and Washington, USA. Quaternary Research 61, 193-203.

Jackson, L.E., Andriashek, L.D., Phillips, F.M., 2011. Limits of successive middle and late Pleistocene continental ice sheets, interior plains of southern and central Alberta and adjacent areas. Developments in Quaternary Science 15, 575-589.

Jackson, L.E., Phillips, F.M., Little, E.C., 1999. Cosmogenic ${ }^{36} \mathrm{Cl}$ dating of the maximum limit of the Laurentide Ice Sheet in southwestern Alberta. Canadian Journal of Earth Sciences 36, 1347-1356.
Jackson, L.E., Phillips, F.M., Shimamura, K., Little, E.C., 1997. Cosmogenic ${ }^{36} \mathrm{Cl}$ dating of the Foothills erratics train, Alberta, Canada. Geology 25, 195-198.

Johnson, G.D., McCormick, K.A., 2005. Geology of Yankton County, South Dakota. Bulletin 34. United States Geological Survey.

Kleman, J., Borgström, I., 1996. Reconstruction of palaeo-ice sheets: the use of geomorphological data. Earth Surface Processes and Landforms 21, 893-909.

Kovanen, D.J., Easterbrook, D.J., 2002. Paleodeviations of radiocarbon marine reservoir values for the northeast Pacific. Geology 30, 243-246.

Lajeunesse, P., St-Onge, G., 2008. The subglacial origin of the Lake Agassiz-Ojibway final outburst flood. Nature Geoscience 1, 184-188.

Lepper, K., Buell, A.W., Fisher, T.G., Lowell, T.V., 2013. A chronology for glacial Lake Agassiz shorelines along Upham's namesake transect. Quaternary Research 80 $88-98$.

Lepper, K., Fisher, T.G., Hajdas, I., Lowell, T.V., 2007. Ages for the Big Stone Moraine and the oldest beaches of glacial Lake Agassiz: implications for deglaciation chronology. Geology 35, 667-670.

Lepper, K., Gorz, K.L., Fisher, T.G., Lowell, T.V., 2011. Age determinations for glacia Lake Agassiz shorelines west of Fargo, North Dakota, USA. Canadian Journal of Earth Sciences 48, 1199-1207.

Lepper, K., Sager, L., 2000. A revised age determination for the Embden, North Dakota, mammoth using optically stimulated luminescence dating. Current Research in the Pleistocene 27, 171-173.

Leverington, D.W., Teller, J.T., 2003. Paleotopographic reconstructions of the eastern outlets of glacial Lake Agassiz. Canadian Journal of Earth Sciences 40, 12591278 .

Lewis, C.F.M., Miller, A.A.L., Levac, E., Piper, D.J.W., Sonnichsen, G.V., 2012. Lake Agassiz outburst age and routing by Labrador Current and the $8.2 \mathrm{cal}$ ka cold event. Quaternary International 260, 83-97.

Little, E.C., 2006. Surficial Geology, Ellice Hills (North), Nunavut. Open File 5016 Geological Survey of Canada. Scale 1:50 000.

Little, E.C., Ferbey, T., 2003. Surficial Geology, Laughland Lake South, Nunavut. Open File 4278. Geological Survey of Canada. Scale 1:100 000

Lowdon, J., Blake, W., 1968. Geological Survey of Canada radiocarbon dates VII. Radiocarbon 10, 207-245.

Lowdon, J., Robertson, I., Blake, W., 1971. Geological Survey of Canada radiocarbon dates XI. Radiocarbon 13, 255-324.

Lowell, T., Fisher, T., Comer, G., Haidas, I., Waterson, N., Glover, K., Loope, H. Schaffer, J., Rinterknecht, V., Broecker, W., Denton, G., Teller, J., 2005. Testing the Lake Agassiz meltwater trigger for the Younger Dryas. EOS Transactions 86 365-373.

Lowell, T.V., Fisher, T.G., Hajdas, I., Glover, K., Loope, H., Henry, T., 2009. Radiocarbon deglaciation chronology of the Thunder Bay, Ontario area and implications for ice sheet retreat patterns. Quaternary Science Reviews 28, 1597-1607.

MacDonald, G.M., 1987. Postglacial vegetation history of the Mackenzie River basin. Quaternary Research 28, 245-262.

MacDonald, G.M., Beukens, R.P., Kieser, W.E., 1991. Radiocarbon dating of limnic sediments: a comparative analysis and discussion. Ecology 72, 1150-1155.

McMartin, I., Campbell, J.E., Dredge, L.A., Robertson, L., 2010. A Digital Compilation of Ice-flow Indicators for Central Manitoba and Saskatchewan: Datasets, Digita Scalable Maps and 1:500 000 Scale Generalized Map. Open File 6405 Geological Survey of Canada. Scale 1:500 000.

McMartin, I., Dredge, L.A., 2005. History of ice flow in the Schultz Lake and Wage Bay areas, Kivalliq region, Nunavut. Current Research. 2005-B2. Geological Survey of Canada, 10p.

McMartin, I., Dredge, L.A., Ford, K.L., Kjarsgaard, I.M., 2006. Till Composition, Provenance and Stratigraphy Beneath the Keewatin Ice Divide, Schultz Lake Area (NTS 66A), Mainland Nunavut. Open File 5312. Geological Survey of Canada.

McNeely, R., 1989. Geological Survey of Canada Radiocarbon Dates XXVIII. Paper 88-7. Geological Survey of Canada.

McNeely, R., 2006. Geological Survey of Canada radiocarbon dates XXXV. Current Research. 2006-G. Geological Survey of Canada, 151p.

McNeely, R., Atkinson, D.E., 1995. Geological Survey of Canada radiocarbon dates XXXII. Current Research. 1995-G. Geological Survey of Canada, 151p.

McNeely, R., Brennan, J., 2005. Geological Survey of Canada Radiocarbon Dates XXXV. Open File 5019. Geological Survey of Canada.

McNeely, R., Dyke, A., Southon, J., 2006. Canadian Marine Reservoir Ages, Preliminary Data Assessment. Open File 5049. Geological Survey of Canada.

McNeely, R., Jorgensen, P.K., 1992. Geological Survey of Canada Radiocarbon Dates XXX. Paper 90-7. Geological Survey of Canada.

Meltzer, D.J., 2003. Peopling of North America. In: Gillespie, A., Porter, S., Atwater, B. (Eds.), The Quaternary Period in the United States, Developments in Quaternary Sciences, vol. 1. Elsevier, pp. 539-563.

Morlan, R., McNeely, R., Nielsen, E., 2000. Manitoba Radiocarbon Dates. Open File Report OF2000-1. Manitoba Industry, Trade and Mines, Geological Survey.

Munyikwa, K., Feathers, J.K., Rittenour, T.M., Shrimpton, H.K., 2011. Constraining the Late Wisconsinan retreat of the Laurentide ice sheet from western Canada using luminescence ages from postglacial aeolian dunes. Quaternary Geochronology $6,407-422$

Murton, J.B., 2009. Stratigraphy and palaeoenvironments of Richards Island and the eastern Beaufort Continental Shelf during the last glacial-interglacial cycle. Permafrost and Periglacial Processes 20, 107-125.

Murton, J.B., Bateman, M.D., Dallimore, S.R., Teller, J.T., Yang, Z., 2010. Identification of Younger Dryas outburst flood path from Lake Agassiz to the Arctic Ocean. Nature 464, 740-743. 
Murton, J.B., Frechen, M., Maddy, D., 2007. Luminescence dating of mid-to Late Wisconsinan aeolian sand as a constraint on the last advance of the Laurentide Ice Sheet across the Tuktoyaktuk Coastlands, western Arctic Canada. Canadian Journal of Earth Sciences 44, 857-869.

Nambudiri, E.M.V., Teller, J.T., Last, W.M., 1980. Pre-Quaternary microfossils-a guide to errors in radiocarbon dating. Geology 8, 123-126.

Nielsen, E., Gryba, E.M., Wilson, M.C., 1984. Bison remains from a Lake Agassiz spit complex in the Swan River valley, Manitoba: depositional environment and paleoecological implications. Canadian Journal of Earth Sciences 21, 829-842.

Nielsen, E., Morgan, A.V., Morgan, A., Mott, R.J., Rutter, N.W., Causse, C., 1986. Stratigraphy, paleoecology, and glacial history of the Gillam area, Manitoba. Canadian Journal of Earth Sciences 23, 1641-1661.

Nilsson, M., Klarqvist, M., Bohlin, E., Possnert, G., 2001. Variation in ${ }^{14} \mathrm{C}$ age of macrofossils and different fractions of minute peat samples dated by AMS. The Holocene 11, 579-586.

Not, C., Hillaire-Marcel, C., 2012. Enhanced sea-ice export from the Arctic during the Younger Dryas. Nature Communications 3, 647.

Ogden, J.G., 1977. The use and abuse of radiocarbon dating. Annals of the New York Academy Of Sciences 288, 167-173.

Prest, V.K., 1969. Retreat of Wisconsin and Recent Ice in North America. Map 1257A. Geological Survey of Canada. Scale 1:5,000,000.

Rampton, V.N., 1988. Quaternary Geology of the Tuktoyaktuk Coastlands, Northwest Territories. In: Memoir, vol. 423. Energy, Mines and Resources, Canada.

Reimer, P.J., Baillie, M.G.L., Bard, E., Bayliss, A., Beck, J.W., Blackwell, P.G., Bronk Ramsey, C., Buck, C.E., Burr, G.S., Edwards, R.L., Friedrich, M., Grootes, P.M. Guilderson, T.P., Hajdas, I., Heaton, T.J., Hogg, A.G., Hughen, K.A., Kaiser, K.F. Kromer, B., McCormac, F.G., Manning, S.W., Reimer, R.W., Richards, D.A Southon, J.R., Talamo, S., Turney, C.S.M., van der Plicht, J., Weyhenmeyer, C.E., 2009. IntCal09 and Marine09 radiocarbon age calibration curves, 0-50,000 years cal BP. Radiocarbon 51, 1111-1150.

Risberg, J., Sandgren, P., Teller, J.T., Last, W.M., 1999. Siliceous microfossils and mineral magnetic characteristics in a sediment core from Lake Manitoba, Canada: a remnant of glacial Lake Agassiz. Canadian Journal of Earth Sciences 36, 1299-1314.

Ross, M., Utting, D.J., Lajeunesse, P., Kosar, K.G.A., 2012. Early Holocene deglaciation of northern Hudson Bay and Foxe Channel constrained by new radiocarbon ages and marine reservoir correction. Quaternary Research 78, 82-94.

Roy, M., DellOste, F., Veillette, J.J., de Vernal, A., Hélie, J., Parent, M., 2011. Insights on the events surrounding the final drainage of Lake Ojibway based on James Bay stratigraphic sequences. Quaternary Science Reviews 30, 682-692.

Ruhe, R.V., 1969. Quaternary Landscapes in Iowa. Iowa State University Press.

Sado, E.V., Fullerton, D.S., Goebel, J.E., Ringrose, S.M., 1995. Quaternary Geologic Map of the Lake of the Woods 4 Degrees X 6 Degrees Quadrangle, United States and Canada. USGS Numbered Series I-1420(NM-15). U.S. Geological Survey. Scale 1:1000 000 .

Seppä, H., Cwynar, L.C., MacDonald, G.M., 2003. Post-glacial vegetation reconstruction and a possible $8200 \mathrm{cal}$. yr BP event from the low arctic of continenta Nunavut, Canada. Journal of Quaternary Science 18, 621-629.

Shore, J.S., Bartley, D.D., Harkness, D.D., 1995. Problems encountered with the ${ }^{14} \mathrm{C}$ dating of peat. Quaternary Science Reviews 14, 373-383.

Slimmon, W.L., 2011. Geological Atlas of Saskatchewan. Miscellaneous Report 20117. Saskatchewan Ministry of Energy and Resources.

Smith, D.G., 1992. Glacial Lake Mackenzie, Mackenzie Valley, Northwest Territories, Canada. Canadian Journal of Earth Sciences 29, 1756-1766.

Smith, D.G., 1994. Glacial Lake McConnell: paleogeography, age, duration, and associated river deltas, Mackenzie River basin, western Canada. Quaternary Science Reviews 13, 829-843.

Smith, I.R., Paulen, R.C., Plouffe, A., 2007. Surficial Geology, Mega River, Alberta. Open File 5237. Geological Survey of Canada. Scale 1:100 000.

Swinehart, J.B., Dreeszen, V.H., Richmond, G.M., Tipton, M.J., Bretz, R., Steece, F.V., Hallberg, G.R., Goebel, J.E., 1994. Quaternary Geologic Map of the Platte River
Degrees X 6 Degrees Quadrangle, United States. USGS Numbered Series I-1420(NK-14). U.S. Geological Survey. Scale 1:1 000000.

Tarasov, L., Dyke, A.S., Neal, R.M., Peltier, W., 2012. A data-calibrated distribution of deglacial chronologies for the North American ice complex from glaciological modeling. Earth and Planetary Science Letters 315-316, 30-40.

Tarasov, L., Peltier, W., 2005. Arctic freshwater forcing of the Younger Dryas cold reversal. Nature 435, 662-665.

Teller, J.T., 1989. Importance of the Rossendale site in establishing a deglacial chronology along the southwestern margin of the Laurentide ice sheet. Quaternary Research 32, 12-23.

Teller, J.T., Boyd, M., 2006. Two possible routings for overflow from Lake Agassiz during the Younger Dryas, a reply to comment by T. Fisher, T. Lowell, H. Loope on "Alternative routing of Lake Agassiz overflow during the Younger Dryas: new dates, paleotopography, a re-evaluation". Quaternary Science Reviews 25, 1142-1145.

Teller, J.T., Boyd, M., Yang, Z., Kor, P.S., Fard, A.M., 2005. Alternative routing of Lake Agassiz overflow during the Younger Dryas: new dates, paleotopography, and a re-evaluation. Quaternary Science Reviews 24, 1890-1905.

Teller, J.T., Leverington, D.W., 2004. Glacial Lake Agassiz: a 5000 yr history of change and its relationship to the $\delta^{18} O$ record of Greenland. GSA Bulletin 116, 729-742.

Teller, J.T., Leverington, D.W., Mann, J.D., 2002. Freshwater outbursts to the oceans from glacial Lake Agassiz and their role in climate change during the last deglaciation. Quaternary Science Reviews 21, 879-887.

Teller, J.T., Risberg, J., Matile, G., Zoltai, S., 2000. Postglacial history and paleoecology of Wampum, Manitoba, a former lagoon in the Lake Agassiz basin. Geological Society of America Bulletin 112, 943-958.

Trommelen, M., Ross, M., 2010. Subglacial landforms in northern Manitoba, Canada, based on remote sensing data. Journal of Maps 6, 618-638.

Trommelen, M.S., Ross, M., Campbell, J.E., 2012a. Glacial terrain zone analysis of a fragmented paleoglaciologic record, southeast Keewatin sector of the Laurentide Ice Sheet. Quaternary Science Reviews 40, 1-20.

Trommelen, M.S., Ross, M., Campbell, J.E., 2012b. Inherited clast dispersal patterns: implications for palaeoglaciology of the SE Keewatin Sector of the Laurentide Ice Sheet. Boreas (in press).

Vickers, K., Ward, B., Utting, D., Telka, A., 2010. Deglacial reservoir age and implications, Foxe Peninsula, Baffin Island. Journal of Quaternary Science 25, 13381346.

Wolfe, S., Paulen, R., Smith, I., Lamothe, M., 2007. Age and paleoenvironmental significance of Late Wisconsinan dune fields in the Mount Watt and Fontas River map areas, northern Alberta and British Columbia. Current Research, 2007-B4. Geological Survey of Canada, 10p.

Wolfe, S.A., Huntley, D.J., Ollerhead, J., 2004. Relict late Wisconsinan dune fields of the northern great plains, Canada. Géographie Physique et Quaternaire 58, 323-336.

Wolfe, S.A., Ollerhead, J., Huntley, D.J., Lian, O.B., 2006. Holocene dune activity and environmental change in the prairie parkland and and boreal forest, central Saskatchewan, Canada. The Holocene 16, 17-29.

Wright, H., Watts, W.A., 1969. Glacial and Vegetational History of Northeastern Minnesota. In: Special Publications Series 11. Minnesota Geological Survey.

Yansa, C.H., Ashworth, A.C., 2005. Late Pleistocene palaeoenvironments of the southern Lake Agassiz basin, USA. Journal of Quaternary Science 20, 255-267.

Yu, S.Y., Colman, S.M., Lowell, T.V., Milne, G.A., Fisher, T.G., Breckenridge, A., Boyd, M., Teller, J.T., 2010. Freshwater outburst from Lake Superior as a trigger for the cold event 9300 years ago. Science 328, 1262-1266.

Zazula, G.D., MacKay, G., Andrews, T.D., Shapiro, B., Letts, B., Brock, F., 2009. A late Pleistocene steppe bison (Bison priscus) partial carcass from Tsiigehtchic, Northwest Territories, Canada. Quaternary Science Reviews 28, 2734-2742.

Zreda, M.G., Phillips, F.M., 2000. Cosmogenic nuclide buildup in surficial materials. In: Quaternary Geochronology: Methods and Applications. American Geophysical Union, Washington, pp. 61-76. 